\title{
"Tahiti and Vardø will be the two columns [...]": Observing Venus and Debating the Parallax
}

\begin{abstract}
A precise definition of the Sun's parallax, that is, a definition beyond any doubt, associated with all certitude or at least the highest degree of probability, would not have been possible if it were not for the Supreme King CHRISTIAN the SEVENTH, who followed the advice of Denmark's wisest ministers and entered among the participants in this extremely important enterprise. To the surprise of all other academies, His Highness donated the greatest possible sums for the attainment of this goal and thereby ended up placing what we might call the crown on the head of all the glorious, ruler-sponsored expeditions treated so far.
\end{abstract}

MAXIMILIAN HELL, introduction to "Expeditio litteraria ad Polum arcticum" (unfinished manuscript, $c .1773$, wUs, Manuscripte Hell)

With the third volume of the Expeditio litteraria ad Polum arcticum, both Hell and Sajnovics should be on solid ground. Their professional formation as astronomers and "mathematicians" in the eighteenth-century sense of the word could hardly be contested. Nor is it surprising that, despite the book as such never materializing, the "mathematical-astronomical" part resulted in more pages in print than even the Demonstratio and the polemics entailed. In brief, the third volume was to consist of the following works:

\section{Volume 3. Mathematicus, \& astronomicus}

Part 1: The latitude and longitude of Vardø, description of the observatory and instruments used in Vardø during 1768-69, the refraction of the atmosphere in the Far North, the observation of the transit of Venus itself, and an accurate determination of the solar parallax; Part 2: Geographical latitudes determined en route between Copenhagen and Vardø; Part 3: Observations pertaining to the declination of the magnetic needle; Part 4: A new method to determine the figure of the earth, by means of barometric observations. 
Although not in the framework of the Expeditio litteraria, the first part was effectively published as the Observatio transitus Veneris [...] 1769 (after the first edition in Copenhagen in February 1770, three further Latin editions as well as a Danish translation were issued later in the same year). One particular part of this work, on how to determine the latitude by means of stars culminating in the same zenith distance, was the subject of a more elaborate account in the Ephemerides (1774). ${ }^{1}$ As for the "accurate determination of the solar parallax" meant to be included in the Expeditio litteraria, this instead took the form of two intricate and polemical pamphlets, issued as appendices to the Ephemerides (1772 and 1773).

The second part of the third volume would consist of contributions to the geography of western Scandinavia. Hell presented a report on his latitude determinations made en route between Copenhagen and Vardø to the Royal Society of Sciences just before leaving Copenhagen in May 1770. It was translated into Danish and printed in the proceedings of the Copenhagen society in the same year. ${ }^{2}$ Not until 1790 was an (enlarged) edition of the Latin original issued in Vienna, as a supplement to the Ephemerides for the year 1791. Maps were also made, among them a frequently reprinted map of the Island of Vardø, and maps of "Norway, Nordland, and Finnmark." The latter three should in modern terms represent southern Norway, the present-day counties of Nordland and Troms and Finnmark. According to Hell, he sent test-prints of these maps to the Copenhagen Society of Sciences around 1778, but these have not been found. ${ }^{3}$

1 Maximilian Hell, "Methodus astronomica Sine usu Quadrantis, vel Sectoris, aut alterius cujusvis instrumenti, in gradus Circuli divisi, item sine notitia refractionis, ope solius tubi instructi micrometro filari, singula secunda indicante, et in apto ad hunc usum fulcro mobili applicati, elevationem Poli cujusvis loci, in continente siti, accuratissimam definire," Ephemerides 1775 (1774), 3-41. This has been described as the Horrebow-Talcott method, named after Peder Horrebow the Elder and Andrew Talcott (1797-1883), see, e.g., Peter Brosche, "Küstner's Observations of 1884-85: the Turning Point in the Empirical Establishment of Polar Motion," International Astronomical Union Colloquium 208 (2000): 101-8.

2 Maximilian Hell, "Nogle Steders Geographiske Breder." The Latin original is today preserved at the National Library in Oslo, MS $4^{\circ} 16$.

3 Maximilian Hell, "Observationes astronomicae latitudinum, \& longitudinum locorum borealium Daniae, Sueciae, Norvegiae, \& Finnmarchiae Lapponicae per iter arcticum annis 1768, 1769, \& 1770 factae," Ephemerides 1791 (1790): 300-86, here 310: "These maps, engraved on copper, were sent to the highly illustrious Society of Sciences in Copenhagen already twelve years ago." These maps were for a time in the hands of prominent Norwegian historian Gerhard Schøning (1722-80), who has left a brief report on the names of places they included. It is not known whether these maps exist today (cf. Kristian Nissen's manuscript "Pater Hells Norgeskarter fra tiden omkring 1770," intended as a chapter in the unpublished Bidrag til Norges karthistorie, III [National Library of Norway, Oslo. MS $4^{\circ}$ 3051:c7]). 
The third part of the third volume, on measurements of the declination of the magnetic needle, has survived in manuscript but was not published until $2005 .{ }^{4}$ The fourth part is not extant, either in manuscript or in any printed version. By means of barometrical observations, Hell argued, it should be possible to determine the curvature of the Earth's surface far more accurately than Maupertuis had done some decades earlier. ${ }^{5}$ Hell never published this partperhaps fortunately for him, as this marvelous idea was surely a dead end.

Highest among Hell's priorities, obviously, was publication of his Venus transit report from Vardø, followed shortly afterward by calculations of the solar parallax. However, whereas his plans involved a straightforward process of summarizing, calculating, and publishing a definite result, he was soon provoked into an all-out attack on real and perceived enemies. These included colleagues across Europe that he had earlier considered as friends and collaborators.

\section{Mission Accomplished}

To begin with, the determination of the exact coordinates of all observational sites was of crucial importance to the Venus transit project. Hell planned to determine the longitude of Vardø by various means. In addition to a solar eclipse that was expected around midday on June 4, 1769, he intended to make use of occultations of satellites of Jupiter; a lunar eclipse that was to take place on December 23, 1768; occultations of fixed stars by the moon; and transits of the moon through the meridian compared to the positions of stars. Accordingly, he contacted Wargentin beforehand, asking him to provide corresponding datasets from Sweden. ${ }^{6}$ In Vardø, however, all these attempts failed, partly

4 Lynne Hansen and Aspaas, Maximilian Hell's Geomagnetic Observations; Aspaas and Lynne Hansen, "Geomagnetism by the North Pole." Cf. Lajos Bartha, "Magyar tudósok mágneses megfigyelései a sarkkörön túl 1769-ben," Földrajzi Múzeumi Tanulmányok 13 (2004): 49-55.

5 A particularly valuable source not appreciated on this account is Christian Mayer's lengthy treatise on the 1769 transit of Venus. Mayer elaborates on the potentials of using barometric observations from various places as a means to settle several questions, among them the figure of the Earth: "For this reason, Honorable Father Hell, that famous astronomer of Vienna, has distributed more than twenty diligently calibrated barometers, which he had brought with him from Vienna, to curious and able observers at various places along his journey, so that he thereafter, upon his return from Vardøhus may receive their observations." Mayer, Ad Augustissimam Russiarum omnium Catharinam II Alexiewnam Imperatricem expositio de transitu Veneris, 314-23, here 317.

6 Hell to Wargentin, dated Copenhagen, June 30, 1768 (CVH): "I would like to ask You to make known to your colleagues and correspondents this proposal of mine: that they care to obtain astronomical observations, especially such that pertain to the determination of the 
because of the high southern declination of Jupiter, partly because of overcast weather. The only feasible data Hell obtained were those of the solar eclipse that took place the day after the transit, as well as the observation of the transit itself. ${ }^{7}$ However, the use of the Venus transit data for the purpose of determining the longitude would only be of indirect value, as a crosscheck after the solar parallax had been calculated. At the time Hell wrote his Venus transit report from Vardø, this was way too early, since only European observations had reached him by then. ${ }^{8}$ As for the solar eclipse, this was obviously followed closely not only by Hell and other astronomers on Venus transit expeditions across the world but also by staff at all the high-standard observatories of Europe. For observing the eclipse, Hell used the eight-and-a-half-feet long telescope, and Sajnovics the ten-and-a-half-feet. According to Hell's report, the two astronomers determined the end of the eclipse as identically as could be, only a single second differing between them. ${ }^{9}$

Having returned to Copenhagen in the autumn of 1769 , Hell was able to calculate the longitude of Vardø by means of corresponding observations of the solar eclipse of June 1769 provided by Maskelyne in Greenwich, Messier in Paris, Christian Horrebow and assistants in Copenhagen, Wargentin and Bengt Ferrner in Stockholm, Christian Mayer in St. Petersburg, Pilgram and the amateur Sambach in Vienna, and Cäsar Aman (Amman, 1727-92) in Ingolstadt. ${ }^{10}$ In this way, he found a longitude of $3^{\mathrm{h}} 14^{\mathrm{m}} 41.8^{\mathrm{s}}$ east of the island Ferro, or $1^{\mathrm{h}} 55^{\mathrm{m}}$ $6^{\mathrm{s}}$ east of Paris, corresponding to $2^{\mathrm{h}} 4^{\mathrm{m}} 27^{\mathrm{s}}$ east of Greenwich. ${ }^{11}$ As Hell saw it, however, this was only a preliminary result, for he was still waiting to check his figure on the basis of Venus transit reports from "America" (which in Hell's parlance included the Pacific).

The site of Hell's observatory is nowadays determined as $31^{\circ} 6^{\prime} 27^{\prime \prime}$, or $2^{\mathrm{h}} 4^{\mathrm{m}}$ $25.9^{\mathrm{s}}$ east of Greenwich. This means Hell's initial determination was only

longitude - that is, the moons of Jupiter, eclipses of the Sun and Moon, occultations of fixed stars by the moon, or transits of the moon through the meridian compared with positions of fixed stars - and that they show me the kindness of sharing these observations with me." It is likely that Hell asked colleagues at other sites for similar observations, but no other letters have been available for the present study.

7 Hell, Observatio transitus Veneris [... 1769, 30-31.

8 Hell, Observatio transitus Veneris [...] 1769, 31.

9 That is, within a margin of error of $\pm 1 / 2$ second (cf. Hell, Observatio transitus Veneris [...] 1769,31 ). Other observations of the same moment made at identical sites by multiple observers varied up to \pm 5 seconds (cf. Hell, Observatio transitus Veneris [...] 1769, 33-42, esp. $38)$.

$10 \quad$ Hell, Observatio transitus Veneris [...] 1769, 33-45.

11 Hell, Observatio transitus Veneris [...] 1769, 50 (mentioning only Ferro and Paris). We are indebted to astronomer Truls Lynne Hansen, former head of Tromsø Geophysical Observatory, for calculating the Greenwich value. 
incorrect by 1.1 seconds, or 170 meters. ${ }^{12}$ It is important to note, however, that this remarkable accuracy resulted from a bit of luck as well as excellent observational and calculating skills. With the data at hand, Hell might as well have opted for, say, $2^{\mathrm{h}} 4^{\mathrm{m}} 24^{\mathrm{s}}$ or $2^{\mathrm{h}} 4^{\mathrm{m}} 29^{\mathrm{s}}$. It would still have been a very good determination by eighteenth-century standards. ${ }^{13}$

For the determination of the latitude, Hell used a more unusual method, which merits some consideration. There was a widespread notion in contemporary astronomy that the atmosphere in the north was thicker and the refraction greater than in, for example, Paris, where the best tables of refraction had been made. ${ }^{14}$ Consequently, Hell was puzzled how to test the accuracy of his quadrants as well as the geographical position of his observatory. His choice was to use a selection of pairs of stars culminating in the same zenith distance, one in the north and the other in the south. In this way, any influence of a thicker atmosphere was eliminated:

In the ordinary method, stars of no particular position are chosen- that is, some stars culminating at various zenith distances in the south, others in the north. That procedure requires that the refraction of the atmosphere is accurately determined and known to the observer [...]. But this is not so in my method, [where] the effect of the refraction, however great or small that may be, [is ruled out].15

After a long series of observations, of which only an extract is given in the Venus transit report, Hell concludes that the latitude of his observatory in Vardø was $70^{\circ} 22^{\prime} 36^{\prime \prime}$ north. ${ }^{16}$

12 We are indebted to Bjørn Geirr Harsson of the Norwegian Mapping and Cadastre Authority (Statens Kartverk) and Truls Lynne Hansen for this determination.

13 We rely on Truls Lynne Hansen for this assessment.

14 See, e.g., Gottfried Heinsius, "De refractionibus in oris septentrionalibus," NcASIP (1758/59; published 1761): 412-44, where the author begins his discussion by stating that he finds it logical that the refraction be greater in the north than close to the equator, but concludes by affirming that this is not the case. Also, Hell admits that he was convinced that the refraction would be greater in Vardø than in Paris, and explains that his wish to examine the as-yet unexplored degree of refraction at the seventieth latitude was the main reason for him to spend the winter in Vardø (Hell, Observatio transitus Veneris [...] 1769, 17): "This doubt, of the utmost importance, was certainly the most important among the motives leading me to spend the winter in Vardøhus."

15 Hell, Observatio transitus Veneris [...] 1769, 7-29; here 10-11. See also Hell's article "Methodus astronomica Sine usu Quadrantis," esp. 5.

16 Hell, Observatio transitus Veneris [...] 1769, 17-29, esp. 27. 
A more straightforward method of calculating the latitude was to observe the apparent distance of the Sun's upper limb from the horizon when it reached its highest point at noon. This method yielded data of sufficient accuracy for the needs of ordinary navigation, but not for the delicate calculations of the solar parallax, where each observatory had to be determined as exactly as possible. The method presupposed, for example, that the refraction of the site was exactly known. On his trip back and forth, Hell used this less exact method to determine the latitude of thirty-seven sites between Copenhagen in the south and Vardø in the north. He estimated the degree of uncertainty involved in these measurements to be around $\pm 15^{\prime \prime}$, or for some around $\pm 30^{\prime \prime} .{ }^{17}$ Fifteen arc seconds in the latitude would equal only $0.05 \mathrm{~mm}$ on the circle of the quadrant during observation, ${ }^{18}$ making it hard to believe that Hell's claim to an uncertainty of only \pm 15 "is a reliable figure. It may be added that for surveys in central parts of Sweden around the mid-eighteenth century, an uncertainty of $\pm 30^{\prime \prime}$ was deemed acceptable, whereas Hellant in his surveys of Lapland argued that $\pm 1^{\prime}$ must suffice. ${ }^{19}$

It would have been interesting to learn whether Hell tested the two methods comprehensively against each other in Vardø. However, neither his Venus transit report nor his subsequent treatises on the solar parallax give any evidence of this. ${ }^{20}$ In order to answer this question, we need to look into the letters of

17 Maximilian Hell, "Nogle Steders Geographiske Breder," 622; repeated in Hell, "Observationes astronomicae latitudinum," 309-10.

18 Personal communication from Truls Lynne Hansen, based on the study of Hell's descriptions of Niebuhr's quadrant. The radius of the quadrant is stated to be two feet in Hell, "Nogle Steders Geographiske Breder," 621-22; Hell "Latitudines geographicae," fol. 4, and in Hell, "Observationes meteorologicae," 308-9. The same size is given in a letter from Niebuhr to Franz Xaver von Zach in Gotha, dated Meldorf, July 9, 1801 (originally published in von Zach's Monatliche Correspondenz zur Beförderung der Erd- und Himmelskunde 4 [September 1801]: 240-53, here 244: "Mayer had made for me a quadrant of two-foot radius for observations on land." In a more detailed description in Hell's MS "Observationes astronomicæ et Cæteræ Jn Jtinere litterario Viennâ Wardoëhusium usque factæ" [1768-69], [1], the radius of the quadrant is said to be one foot and two Viennese inches, whereas its tube was two feet and two inches. Probably, "I ped. II dig." is a slip of the pen for "II ped. II dig." In that case, the exact radius of Niebuhr's quadrant was two feet and two inches, or twenty-six inches).

19 Cf. Sven Widmalm, Mellan kartan och verkligheten: Geodesi och kartläggning, 1695-1860, Institutionen för idé- och lärdomshistoria, Uppsala universitet, Skrifter 10 (Uppsala: Institutionen för idé- och lärdomshistoria, Uppsala universitet, 1990), 79.

20 Admittedly, Hell mentions an initial result of $70^{\circ} 20^{\prime}$ for the pole height in a more elaborate treatise on his method of calculating the latitude, but gives no details as to whether he cross-checked this result with other solar observations later in his stay in Vardø. Hell, "Methodus astronomica Sine usu Quadrantis," 31. 
Hell and Sajnovics, the travel diary of Sajnovics, and other surviving manuscripts from the Vardø expedition. (The term "pole height" used below means geographical latitude.)

Writing from Vardø to his replacement at the Vienna University Observatory, Father Pilgram, Hell states that upon his arrival in the island on October 11,

my first wish was to acquire a preliminary knowledge of the latitude, but I had as yet no suitable place at hand from which to conduct this work; I measured from the entrance hall some altitudes of the Sun at noon, and have $[\ldots]$ found the pole height to be between $70^{\circ} 19^{\prime} 30^{\prime \prime}$ and $70^{\circ} 20^{\prime}$. This result is only preliminary, however, until I determine it accurately by means of observations of the vertical stars. ${ }^{21}$

In a letter to Horrebow on the same day, November 12, 1768, he mentions the same result, adding that it was the travelers' quadrant of Niebuhr that had been used for this measurement. ${ }^{22}$ In various other letters from Vardø between November 1768 and January 1769 , Hell speaks of a latitude of $70^{\circ} 20^{\prime}$, but without explaining the methods used for this determination. ${ }^{23}$

21 Hell to Pilgram, dated Vardø, November 12, 1768, in Pinzger, Hell Miksa, 2:10.

22 Hell to Horrebow, dated Vardø, November 12, 1768, in Pinzger, Hell Miksa, 2:32: "I have here [in Vardø] also measured [the pole height] preliminary and with the same instrument [i.e., Niebuhr's quadrant]. However, partly because of the lack of a proper place to observe from-for I observed in the forecourt [sic], where the quadrant rested on the not entirely fixed wooden floor - partly because the midday sun was already quite low, only four or five degrees high [...], I have found it, by means of four Sun heights at midday and one culmination of the star Altair in the Eagle, to be approximately between $70^{\circ} 19^{\prime} 30^{\prime \prime}$ and $70^{\circ} 20^{\prime} . "$

23 Hell to Gunnerus in Trondheim, dated Vardø, November 12, 1768, in Pinzger, Hell Miksa, 2:26; Hell to Mercier in Copenhagen, dated Vardø, January 15, 1769, wus, relevant part of letter not included in Pinzger; Hell to Horrebow in Copenhagen, dated Vardø, January 15, 1769, wUs. Cf. Sajnovics to Splenyi in Trnava, dated Vardø, November 14, 1768 (MTAK IL): "The Vardø Island is situated at a pole height of approximately $70^{\circ} 20^{\prime}$." Sajnovics's diary gives additional information on the first attempts to determine the latitude of Vardø. In the entry on October 14, it is said that: "The quadrant of Niebuhr was mounted, since clouds full of snow came in intervals and gave us reason to hope for a view to the Sun. The complement of the altitude of the [upper] limb of the Sun was $78^{\circ} 28^{\prime} 30^{\prime \prime}$, giving a pole height of $70^{\circ} 26^{\prime}$, [which is only] an approximation, because clouds disturbed the observation." The entry on October 16, 1768 states that "a wind from ssw melted the snow completely and brought back the serenity in the sky. The complement of the altitude of the Sun's upper limb was $79^{\circ} 9^{\prime}$ o"." Finally, on October 18, Sajnovics says: "I have observed the altitude of the Sun, which gives a pole height of $70^{\circ} 20^{\prime}$." Other entries in the travel diary demonstrate that further attempts to measure the latitude were made as late as October 
Hell's manuscript "Astronomical and Other Observations Made during the Scientific Journey from Vienna to Vardø" (hereafter referred to as his "astronomical notebook") gives additional information. ${ }^{24}$ Here, Hell records even more observations of the Sun than those that are found in Sajnovics's diary, and what is more, the observations are accompanied with calculations and sometimes even theoretical deliberations. The conspicuous difference between the preliminary results of November 1768 and the final conclusions in the printed report-from around $70^{\circ} 20^{\prime}$ or even $70^{\circ} 19^{\prime} 30^{\prime \prime}$, to $70^{\circ} 22^{\prime} 36^{\prime \prime}$-is explained by the error of the quadrant, which had not yet been determined in the autumn. ${ }^{25}$ Thus, when Hell in his notebook on October 16-18, 1768 records observations giving pole heights ranging from $70^{\circ} 20^{\prime} 26^{\prime \prime}$ to $70^{\circ} 21^{\prime} 12^{\prime \prime}$, ending with a mean value of $70^{\circ} 20^{\prime} 25^{\prime \prime}$ (sic), he has added in a slightly different ink, +1 30 error Quadr., and concluded that the pole height should be $70^{\circ} 22^{\prime} 55^{\prime \prime}$. Of course, $70^{\circ} 20^{\prime} 25^{\prime \prime}$ plus $1^{\prime} 30^{\prime \prime}$ does not give $70^{\circ} 22^{\prime} 55^{\prime \prime}$, but $70^{\circ} 21^{\prime} 55^{\prime \prime}$. Neither figure, however, is too far from that of $70^{\circ} 22^{\prime} 36^{\prime \prime}$, which ultimately appeared in the Venus transit report. The difference between the $70^{\circ} 20^{\prime} 25^{\prime \prime}$ in the astronomical notebook of October 1768 and the approximate value of $70^{\circ} 19^{\prime} 30^{\prime \prime}$ or $70^{\circ} 20^{\prime}$ in the letters of November and January suggests that Hell initially believed his quadrant's error to be about $-30^{\prime \prime}$, instead of $+1^{\prime} 30^{\prime \prime}$ (or even $\left.+2^{\prime} 30^{\prime \prime}\right)$. To judge from the astronomical notebook, no further efforts to measure the pole height by means of the Sun were made, not even in late May or June, when the Sun was available day and night and the stars were in any case invisible. ${ }^{26}$

In conclusion, there is nothing in the sources to indicate that Hell bothered about the latitude any more after he had determined it by means of observations of stars during the winter and early spring of $176 \mathrm{~g}$. It is a puzzle why Hell

25 and November 5 , but then the subject is dropped and never mentioned again in this text. Sajnovics, travel diary, draft version (wUs), October 14-November 5, 1768.

24 Hell's MS "Observationes astronomicæ et Cæteræ in itinere litterario Viennâ Wardoëhusium usque factæ" (1768-69). wUs.

25 Hell's MS "Observationes astronomicæ [...]" (1768-69): "[These observations] were also made with Mr. Niebuhr's quadrant, which needs to be examined later."

26 Further observations of solar heights recorded in the astronomical notebook are not concerned with the pole height. Thus, solar observations recorded on November 19-21, 1768 and January 19-21, 1769 contain deliberations concerning effects of the refraction upon the length of the polar night; various observations from January 24 to March 18, 1769 are either implicitly or explicitly undertaken in order to determine refraction; observations are conducted from April 10 to 26, 1769 in order to establish a correct meridian line for observations of magnetic declination; observations from April 29 to June 9, 1769 are evidently made in order to test the running of the clocks; and finally, observations in the night between June 17 and 18, 1769 have the additional aim of checking the refraction (the midnight Sun being very low above the sea level, this was a convenient crosscheck against the results obtained from observations of stars made earlier in the year). 
apparently never undertook a comprehensive, comparative study of the pole height yielded by observations of the Sun versus that yielded by the stars. Incidentally, Hell's final conclusion concerning the latitude of his observatory- $70^{\circ}$ $22^{\prime} 36^{\prime \prime}$ - is today found to be somewhat more inaccurate than his determination of the longitude: it should be $70^{\circ} 22^{\prime} 15.5^{\prime \prime}$ north, that is, 20.5 seconds, or $63^{2}$ meters farther south than Hell's figure. ${ }^{27}$ It is important to note, however, that this modern value depends on more accurate knowledge of the curvature of the Earth's surface than that which existed in the eighteenth century. An overall examination of Hell's activities as a surveyor during his expedition, with assessments of his results in the light of the history of Nordic geodesy, is a desideratum. ${ }^{28}$

In any case, as the third day of June 1769 was approaching, Hell felt that he had safely determined the latitude of his observatory. The running of the clocks had already been tested for weeks, and the frequency of these tests was intensified in the last days before the transit. Ideally, such tests involved observations of the Sun as it passed the meridian in the south at noon and the meridian in the north at midnight. The transit was going to take place when the Sun was in the north, meaning that the northern room of his observatory (the observatoriolum septentrionale) would be used for this crucial observation. Having checked the time-keeping at twelve o'clock in the day, Hell had to move his instruments over to the northern chamber in the afternoon of June 3 in order to be prepared for the transit of Venus. By the next morning-June 4-at least two of his telescopes must have been moved back again, as these were used to

27 Personal communication from Bjørn Geirr Harsson. The astronomical latitude, observed by Hell, is related to the plumb line at the station, whereas the latitude obtained from a GPS receiver is related to the normal at the ellipsoid. "The angle between the plumb line and the vertical of the ellipsoid is called the deflection of the vertical," Harsson explains. "In Vardø the geoid is tilting to east northeast, which means that the deflection of the vertical has a component in direction north, even if the main component is in direction east. The north component of the deflection of the vertical is computed to be 2.5 second of an arc at today's post office in Vardø. So if $2.5^{\prime \prime}$ is added to the GPS-latitude, the two latitudes can be compared. Hell's latitude was $70^{\circ} 22^{\prime} 36^{\prime \prime}$ and the GPS-latitude is $70^{\circ} 22^{\prime} 13^{\prime \prime}$. If we add the $2.5^{\prime \prime}$ to the GPS-latitude we get $70^{\circ} 22^{\prime} 15.5^{\prime \prime}$. The difference of 20.5 seconds corresponds to a latitude for Hell to be 632 meters north of today's GPS position of the same place."

28 An investigation of the latitude for a single location (in Christiania, now Oslo) by Harsson in 2003 gave a discrepancy of only nine arc seconds, or 270 meters between Hell's determination and the modern value. Cf. Per Pippin Aspaas and Nils Voje Johansen, "Astronomen Maximilian Hell: Fra Wien til Vardø for å se Venus," Ottar: Populcervitenskapelig tidsskrift fra Tromsø Museum 249, no. 1 (2004): 3-11, here 5-6. It would be futile, however, to conclude much from the examples of Oslo and Vardø alone. 
observe the eclipse of the Sun, which took place between 9:22 and 11:22 a.m., and would only be visible from the observatoriolum australe. ${ }^{29}$

As the moment of the transit around midnight, June 3-4, 1769 was approaching, other kinds of preparations were made, too. Of the four contacts of Venus with the limb of the Sun, Hell deemed the first exterior contact impossible to observe with anything near the accuracy required. Accordingly, he ordered his assistants Sajnovics and Borchgrevink to be on the look-out for this event "so as to avoid, by this useless staring at the Sun, to weary and weaken my eye, which I wanted to spare for the precise determination of that utterly important, first interior contact." ${ }^{30}$ As soon as the two assistants had exclaimed that they saw "a sort of black thing" (rem quampiam nigram) about to enter the limb of the Sun, Hell placed his eye on the lens of his telescope and estimated, on the basis of the proportion of the disc of Venus that had entered so far, that the real exterior contact had probably taken place some thirty seconds earlier, or 9:14:47 p.m. according to the Viennese clock. Borchgrevink used the ten-foot Dollond, Sajnovics the ten-and-a-half-foot, and Hell the eight-and-a-half-foot telescope for this first observation. ${ }^{31}$

Before the interior contact at ingress (which took place some seventeen minutes later), Hell and Borchgrevink switched places. Hell now took charge of the Dollond and left the eight-and-a-half-foot telescope for Borchgrevink, whereas Sajnovics continued to use the ten-and-a-half-foot. The statement on the interior contact is divided in two: first, Hell records the moment when the Sun and Venus appeared to the three observers to be perfectly round, then, a moment taking place a few seconds later, when "the shining thread of the Sun's limb appears" (Apparet filum lucidum limbi Solis). It is the latter of these moments that Hell considers to be the moment of ingressus totalis Veneris (total ingress of Venus), although he concedes that some observers define the former moment as that of "real," interior contact. The latter moment was seen by Hell at 9:32:48 p.m. according to the Viennese clock, and by Sajnovics three seconds earlier. The amateur observer Borchgrevink in his turn saw it thirty-five seconds earlier than Sajnovics. ${ }^{32}$ Only some seven minutes after total ingress had been observed, clouds started blocking their view to the Sun, and the sky remained overcast nearly continuously until less than half an hour before egress

29 Cf. Hell, Observatio transitus Veneris [...] 1769, 81.

30 Hell, Observatio transitus Veneris [...] 1769, 71-72, here 71.

31 Hell, Observatio transitus Veneris [...] 1769, 71.

32 Hell, Observatio transitus Veneris [...] 1769, 73. 
began. By the time the moments of egress were observed, the sky had again become perfectly clear. ${ }^{33}$

The interior contact of egress is described by Hell somewhat differently from that of interior contact of ingress. Here, Hell speaks of the gutta nigra (black drop), which starts forming some eleven seconds before it "in an instant disappears, and so-to-speak bursts, and the limbs of the Sun and Venus flow together as one."34 Hell and Sajnovics had, according to Hell's account, determined this moment only a single second apart—at 3:26:17 and 3:26:18 a.m., respectively, according to the Viennese clock—whereas Borchgrevink noted what he simply called "the interior contact" (contactus interior) at 3:26:10 a.m. ${ }^{35}$ The moment of total egress was, according to the same account, encumbered with some uncertainty. However, it was observed by Hell, Sajnovics, and Borchgrevink within a range of seven seconds, the moment expressly stated as egressus certus (certain egress) being recorded by Sajnovics and Hell only a second apart—at 3:44:26 and 3:44:27 a.m., by the Viennese clock. ${ }^{36}$

The above extract is based upon the printed report alone. Moreover, it does not render justice to the intricate theoretical deliberations accompanying the data. The account of the observation itself is found very near the end of the eighty-two-page report, after an elaborate account of instruments used, procedures followed in the testing of the clocks, definitions of "true" and "optical" contacts, the black drop effect, and so forth. This feature of Hell's report is- to the best of our knowledge - unparalleled in all other Venus transit reports of the year 1769: no other observer produced a first edition of his observation that included such long and intricate theoretical discussions. But where theory and detail might be an advantage in a report of such momentum, the time consumed in writing and publishing it was not. As explained previously, Hell took his time when traveling back to Copenhagen, which they did not reach until October 17 (covering nearly the same period of the year, and following roughly the same route, as on their outward journey in 1768). Here, during three sessions at the Royal Society-November 24, and December 1 and 8, 1769-Hell presented his report on the Venus transit observation from Vardø. ${ }^{37} \mathrm{He}$ also had an audience with King Christian VII on November 29, during which he obtained permission to dedicate the printed version of the report to His

33 Hell, Observatio transitus Veneris [...] 1769, 74-75.

34 Hell, Observatio transitus Veneris [...] 1769, 75-76, here 76.

35 Hell, Observatio transitus Veneris [...] 1769, 76.

36 Hell, Observatio transitus Veneris [...] 1769, 76 .

37 Sajnovics's travel diary 1768-70 (wUs), entries on November 24 and December 1 and 8, 1769; the protocol of the Royal Danish Society of Sciences (DKDVs), entries November 24 and December 1 and 8, 1769 . 
Majesty. ${ }^{38}$ The printing process took its time, however, and not until February 8, 1770 could Hell present a copy of the work to its dedicatee. ${ }^{39}$ Immediately afterward, copies were distributed to learned societies and individual savants abroad. ${ }^{40}$

During the eight months of secrecy between observation and publication, no foreign astronomer was given access to datasets from Vardø. This caused suspicion and even anger among some of Hell's colleagues abroad. Most astronomical datasets are useless unless they are compared with corresponding observations from other sites, and this was true to an extreme degree as far as the eighteenth-century Venus transits were concerned. This was the last chance for more than a century to obtain data for the determination of that coveted measure, the solar parallax; and in 1769, those from the High North of Europe were, along with corresponding ones from the Southern Pacific, more precious than observations from anywhere else in the Old World.

Because of such features, perhaps like no other scientific project of the age, the Venus transit enterprise embodied notions and practices of interpersonal dynamics associated both with the Republic of Letters and the ways in which it was understood to mirror the realities of complex, modern European societies at large. With regard to its patronage and its composition, the expedition led by Hell was a counterpart of several dozen similar ones taking place simultaneously all around the northern hemisphere, and a microcosmic version of

38 Sajnovics's travel diary 1768-70 (wUs), entry November 29, 1769: “When Reverend Father Hell asked him if he would allow the Observatio transitus Veneris that is going to be printed, to be dedicated to His Royal Name, the king answered: 'That will be a pleasure to me." Sajnovics's travel diary 1768-70 (wUs), entry February 8, 1770: “Around 4 o'clock, we went to the palace. At about 5 o'clock, His Highness the King opened the door. Honorable Father Hell offered him a copy of the Observatio. He accepted it very generously and inspected it for a while. Then he kept talking for about half an hour, mentioning the northern light, the decrease of the sea level, the language of the Hungarians and the Lapps, etc., and finally, the quadrature of the circle. It emerged from all this that the king had been quite well informed concerning the works of Father Hell. He also demonstrated quite clearly that his own as well as the others' expectations had been amply fulfilled."

Hielmstierne to Johann Albrecht Euler in St. Petersburg, dated February 9, 1770 (archives of the Rossiiskaia Akademiia Nauk, hereafter: RAN); Hielmstierne to Wargentin in Stockholm, dated Copenhagen, February 10, 1770 ( $\mathrm{CVH})$. These examples corroborate a claim made by Hell in the "De parallaxi Solis [...]," 110, that his Venus transit report was published in Copenhagen on February 8 and distributed by the post "to all academies" the next day. 
what they, taken together, constituted: a gigantic international enterprise of eighteenth-century field science. This project of national-stately self-assertion through royal-governmental patronage to an expedition likely to earn prestige was inevitably embedded in a thoroughly cosmopolitan context, and from the perspective of the participating individual scholars and teams, the emulative drive had to be tempered by a sense of collegiality, while the lofty ideal of harmonious collaboration for the shared purpose of the advancement of knowledge was qualified by several sobering realities. ${ }^{41}$ In many ways, the complexities of knowledge production were not unlike those involved in any other set of contemporary communicative practices that could be modeled after the then relatively newly discovered experience of the market, which depended on the maximization of one's profit by satisfying the needs of one's partners: it was exactly in the 1760 s and 1770 s that Adam Smith (1723-90) worked out his highly influential anthropology of commercial and sociable man. ${ }^{42}$ Whether at the marketplace, the stock exchange, the coffee-house, the assembly room, or the academy, men and women were in the first place seeking their own good. But what they coveted - a fair price, a good conversation, the applause and admiration of fine society, or recognition of scientific achievement-was understood as a matter of giving as well as taking. For, in the course of such exchanges, each of the parties felt that their own interests were best served if they placed themselves - to speak with Smith, as "impartial spectators" - in the position of the others, applying the faculty of empathy to perceive their interest in the transaction. ${ }^{43}$

Immanuel Kant (1724-1804) was to call ungesellige Geselligkeit, unsocial sociability, the paradoxical disposition of fellow feeling arising from reasonable and enlightened self-regard. ${ }^{44}$ Science was no exception. On the contrary, it could be understood as a social realm in which personal vanity and ambition

41 We have been reminded of the tension between such ideals and realities in the Republic of Letters (and of science), among others, by Lorraine Daston, "The Ideal and Reality of the Republic of Letters in the Enlightenment," Science in Context 4 (1991): 367-86; Adrian Johns, "The Ideal of Scientific Collaboration: The 'Man of Science' and the Diffusion of Knowledge," in Commercium litterarium, 1600-1750: La communication dans la république des lettres/Forms of Communication in the Republic of Letters, ed. Hans Bots and Françoise Waquet (Amsterdam: Apa-Holland University Press, 1994), 3-22.

42 Adam Smith, An Inquiry into the Nature and Causes of the Wealth of Nations, ed. R.H. [Roy Hutcheson] Campbell and A.S. [Andrew Stewart] Skinner (Indianapolis: Liberty Classics, 1981), book 1, Chapter 2, 1:26.

43 Adam Smith, The Theory of Moral Sentiments, ed. D.D. [David Daiches] Raphael and A.L. [Alec Lawrence] Macfie (Indianapolis: Liberty Classics, 1982), book 3, chapter 1.5, 112.

44 For important reconstructions of this tradition of thought, see Richard Tuck, Philosophy and Government, 1572-1651 (Cambridge: Cambridge University Press, 1993); Knud 
almost imperceptibly collapsed into and drew mutual reinforcement from one another with an ethics of service to mankind through the production of useful knowledge. Even among the numerous instances in which this could be demonstrated, the Venus transit represents a liminal case, where success depended on international cooperation and the sharing of research results on an unparalleled scale. As already noted, the results of 1761 being unsatisfactory, the number of observational posts increased by $1769 .{ }^{45}$ The most famous expedition assigned, among many other tasks, to observe the 1769 transit of Venus, was undoubtedly that of Cook, the location in this case being the island of Tahiti. Cook's $1768-71$ circumnavigation, of which the transit observation was to be a principal episode, was also paradigmatic in the sense that it perhaps most colorfully represented the unprecedented dimensions of cross-disciplinary effort manifest in the ventures: astronomical-geographical-cartographic measurement was to be accompanied with the collection of botanical, zoological, and mineralogical specimens as well as cultural, historical, and anthropological inquiry into the customs and manners, institutional and religious practices, languages, and so on of the indigenous inhabitants of the lands hitherto unexplored by Europeans ${ }^{46}$ But Cook's venture was only one, albeit the most complex and for obvious reasons the best known, among many, the others differing from it in scale rather than kind, whether they took place in the Pacific, in California, at the Hudson Bay in Canada, in Scandinavia, or in the Kola Peninsula in northwest Russia. ${ }^{47}$ The many dozens of Britons, Frenchmen, Russians, and

Haakonssen, Natural Law and Moral Philosophy: From Grotius to the Scottish Enlightenment (Cambridge: Cambridge University Press, 1996).

45 See above, 136.

46 The complex cross-disciplinary effort of the voyage is well documented in the vast literature on Cook and the Pacific since the 1980s. On the strictly astronomical aspects, see Richard van der Riet Woolley, "The Significance of the Transit of Venus," in Captain Cook: Navigator and Scientist, ed. G.M. [Geoffrey Malcolm] Badger (Canberra: Australian National University Press, 1970), 118-35; Wayne Orchiston, "From the South Seas to the Sun: The Astronomy of Cook's Voyages," in Science and Exploration in the Pacific: European Voyages to the Southern Ocean in the Eighteenth Century, ed. Margarette Lincoln (Woodbridge: Boydell Press/National Maritime Museum, 1998), 55-72.

47 On the fortunes and achievements of some of these teams, see Woolf, Transits of Venus, passim; Helen Sawyer Hogg, "Out of Old Books: The 1769 Transit of Venus, as Seen from Canada," Journal of the Royal Astronomical Society of Canada 41 (1947): 319-26; Hogg, "Out of Old Books: Le Gentil and the Transits of Venus, 1761 and 1769," Journal of the Royal Astronomical Society of Canada 45 (1951): 37-44, 89-92, 127-34, 173-78; Angus Armitage, "Chappe d'Auteroche: A Pathfinder for Astronomy," Annals of Science 10 (1954): 277-93; Nunis, 1769 Transit of Venus; Don Metz, "William Wales and the 1769 Transit of Venus: Puzzle Solving and the Determination of the Astronomical Unit," Science and Education 18, no. 5 (2009): 581-92; Jean-Loius Pictet and Jacques-André Mallet, Deux astronomes 
others were supposed to send the data they collected to the Académie Royale des Sciences in Paris, where the French astronomers led by Lalande were to synthesize the results.

Let us first see what Sajnovics and Hell reveal on the observation of the transit prior to the publication of February 1770. Sajnovics's travel diary (which was in any case not a public document) gives an idea of the suspense felt when the important day arrived:

June 3, Saturday. This day was the cause and origin of our expedition.

Although the sky had been totally overcast yesterday evening, around three o'clock the clouds spread sufficiently to make the Sun distinctly visible, before the sky again was covered by clouds. Around four o'clock, after the Mass, these clouds disappeared and the clearest of skies appeared, allowing the altitudes [of the Sun] to be recorded. Bands of clouds, purely white and very similar to northern lights, were drifting in various directions, by a gentle breeze arriving from the north at first, then from the west and south, until it around eleven o'clock [a.m.] turned to the east before returning to the south soon after, only to arrive from the west at one o'clock [p.m.]. The culmination of the Sun in the meridian line was recorded, and after lunch corresponding heights were observed. Around three o'clock, as these operations came to a close, the sky was totally covered by small, white clouds, which were not connected with each other. The horizon in the north and south, however, was still rather clear. A gentle breeze blew from the southwest. Shortly afterward, there arrived such a multitude of clouds from the southwest that the student Borchgrevink could not be set to work to observe the Sun until six o'clock, when the Sun again broke through the clouds from time to time and he received his instructions for observing. The same clouds continued until eight o'clock. After nine o'clock [p.m.], we directed the three telescopes to the Sun, which broke through the clouds every now and then. And finally, when the Sun stayed in such a place, the exterior and interior contacts [of ingress] were observed, thanks to the singular grace of God. The merchant exploded his gun nine times, and raised the flag as a sign of joy. The commander followed his example, and made sure the flag at the fortress

genevois dans la Russie de Catherine II:Journaux de voyage en Laponie russe [...] pour observer le passage de Vénus devant le disque solaire 1768-1769, ed. Jean-Daniel Candaux et al. (Ferney-Voltaire: Centre international d'étude du Xviı Ie siècle, 2005); Nils Voje Johansen, "The Expeditions of William Bayly and Jeremiah Dixon to Honningsvåg and Hammerfest, 1769," in Sterken and Aspaas, Meeting Venus, 59-69. 
was raised as well. Guests were allowed into the chambers of the observatory, and Venus in the Sun shown to them. But for no more than five minutes was she visible, until the Sun again was covered in black clouds, and no position of Venus - how incredible! but nonetheless true! — could be recorded over the course of six hours. We were all anxious to observe the egress, but no one hoped for this because of black clouds that were glued to the sky, so to speak, in that region where [the planet] was supposed to leave the Sun. Around three o'clock in the morning, a strong wind from the southeast began, and the cloud that covered the Sun was driven away from its position. Thus, the interior and exterior contacts of Venus were well recorded. Again the merchant fired his gun, this time three times six. A great sense of satisfaction spread among all the inhabitants of Vardø. We burst into a Te Deum laudamus with the sincerest of sentiments, and allowed ourselves some rest in the meantime; there was neither time nor the mood to think of the barometer or the magnetic needle.

[June] 4, Sunday, the 3rd after Pentecost.

After Mass for the Holy Trinity, the corresponding altitudes were recorded in the clearest of skies, with some wind from the north. During these operations, at 10:09 [a.m.] according to the Copenhagen clock, the eclipse of the Sun was noted to begin. Honorable Father Hell observed this moment; and I too observed the end. Then the meridian was recorded, and after lunch the corresponding altitudes of the Sun. As I take down the last of these altitudes, suddenly the entire sky is completely filled by the thickest of fog, falling down to the ground like dew or drizzle, covering everything in a darkness that is likely to last for a very long time. How bad if it had been like this yesterday! ${ }^{48}$

As is regularly the case with Sajnovics's diary, his account makes no attempt to give the details of the observations themselves. Thus, neither the moments of contact of Venus with the limb of the Sun, nor the moments of beginning and end of the eclipse, are stated with anything near the degree of exactitude required. Among the surviving manuscripts, these details can only be found in Hell's astronomical notebook. This crucial set of data was, however, apparently never shared with anyone until the formal report was presented to the Royal Society of Copenhagen.

As Hell wrote to one of his Jesuit brethren, on April 6, 1769 (before the observation of the transit, and concerning the linguistic and ethnographic aspects of the expedition-but establishing a general principle), they were going to

48 Sajnovics's diary, entry on June 3, 1769 (wUs). 
report "astonishing things" to their superiors, but for the time being they should "quietly keep these to themselves, for propriety requires that they are first brought to the knowledge of the Danish king." ${ }^{49}$ Hell's sincerity about the first right of access as stipulated by the sponsor of the expedition was called into question, as we shall see, by some contemporaries and by astronomers of subsequent generations, and even in some of the more recent literature..$^{50}$ There is indeed no documentary evidence that such a commitment was ever requested or made. However, this is a kind of instruction that might well have been given orally. The man who was in charge of the Arabia Felix enterprise (in the case of which there was such an explicit obligation), Minister Moltke, was also the host of Hell in Copenhagen in June 1768. The "ban" against private communication of the datasets from Vardø may have been in breach with the ideals and practices of the Republic of Letters, but it was in accordance with Danish procedure under very similar circumstances only a few years earlier. Besides, Hell as a man who must have developed a certain flair for courtly etiquette over his years of service in Vienna may have perceived restraint in regard of publicity as part of his duty even without a "ban," expressed orally or in writing. Finally, this would have also been in the spirit of the familiar Jesuit strategy of seeking intimate contact with potentates and inner circles at court by means of scientific work when visiting non-Catholic countries. ${ }^{51}$

Even the sporadic and rudimentary news reports that appeared in the Viennese press about Hell's team during their nearly year-long stay at Vardø were resented in the Danish capital. ${ }^{52}$ Regarding the transit observation itself, the caution on the part of Hell even included his employer. Thus, when on June 5, 1769 an express letter was sent from Vardø to Baron Thott in Copenhagen, the leader of the expedition revealed nothing except that his observations of both the Venus transit and the solar eclipse had been successful. ${ }^{53}$ Sajnovics, for his

Hell to Höller in Vienna, dated April 6, 1769 (WUS), printed in Pinzger, Hell Miksa, 2:93.

5o "Everyone who had results [i.e., successful observations] to share did so as quickly as possible, everyone except the Jesuit father. Hell knew that he had the trump card in his hand, for observations in the south were of little value if they could not be compared with observations in the north." Helge Kragemo, "Pater Hells Vardøhusekspedisjon: Belyst ved Pater Sainovič’s dagbok 1768-1769," in Willoch, Vardøhus Festning 650 år, 92-125, here 120.

$5^{1}$ See, e.g., Florence Hsia, "Jesuits, Jupiter's Satellites, and the Académie Royale des Sciences" and Nicolas Standaert, "Jesuit Corporate Culture as Shaped by the Chinese," in O'Malley et al., Jesuits, 241-57 and 352-63; and Catherine Pagani, "Clockwork and the Jesuit Mission in China," in O'Malley et al., Jesuits II, 658-77.

$W D$, June 25, 1768, 6; May 6, 1769, 9-12; June 7, 1769, 5-7. The resentment evoked by these accounts in Copenhagen was reported by Mercier on June 28, 1769. See Pinzger, Hell Mik$s a, 1: 78$.

53 Hell to Thott in Copenhagen, dated Vardø, June 5, 1769, in Pinzger, Hell Miksa, 2:102-3. 
part, wrote a similar letter to his Jesuit friends in Hungary, exercising all his powers of eloquence to express his joy over the supreme benevolence of God in securing the most perfect conditions, but silent about any properly scientific aspects:

From May 27 to June 3, we could not see the Sun because of perpetual clouds, and on the last-mentioned day, after we had recorded its corresponding heights, it disappeared in clouds again. Around nine o'clock in the evening, we-myself, Honorable Father Hell, and the student from Trondheim [i.e., Borchgrevink] — stood at our telescopes, our moods fluctuating between hope and fear as we waited in suspense to see whether it would be possible to observe Venus entering the Sun, if it should happen to dive out from the clouds for a little while. Soon afterward an opening in the clouds emerged, and we could see the Sun as if through a window, and both contacts of Venus in ingress were elegantly observed. But not more than five minutes passed by, before the Sun again was enveloped in thick clouds and no longer came forth in its entirety. Dark clouds stubbornly accompanied the Sun for altogether five hours; and we had lost all hope of observing the egress. Our hosts stood there with us, sad, their faces in mourning, and expressing their sorrow and sympathy by means of utter silence. How we ourselves felt, is easier to guess than to describe. Our only hope was that God, if he should wish to do so, would come to our aid with some miracle. Meanwhile, as the time when Venus was supposed to leave the Sun drew closer, the rays of the Sun suddenly began dissolving the extremely thick cloud that stood in their way, finally dispelling it altogether. And behold! The Sun came forth in full splendor, and both contacts of Venus during egress were recorded exactly; with how much joy, with how many thanksgivings to Divine Clemency, I am incapable of expressing. Our hosts, to whom the word 'miracle' is an uncommon, perhaps even ridiculous concept, nonetheless agreed fully that the way in which the appearance of the sky had changed - so neatly and congruously - could not be due to any human or natural causes, but must be ascribed to the utterly exceptional and incredible favor of the Supreme Being. I for my part will cherish the magnitude of this miracle for as long as I live. The Sun then wandered through a very clear part of the sky, and its eclipse was observed most accurately and its passage through the meridian recorded. After lunch, its corresponding heights were again recorded in the clearest of skies, but just as I was busy taking down the very last of these observations, in the same moment a strong wind rose from the north, enveloping the sky, earth, and sea in the darkest 
of clouds. From that moment onward, the Sun has not been possible to observe, although it is by now the sixth day of June. ${ }^{54}$

As time passed by, the secretive descriptions became more and more sophisticated. Father Hell's letter to Wargentin, dated Copenhagen, November 7, 1769, is a good example:

I have received Your highly friendly letter, eminent fellow, in which You congratulate me on my successful return from Lapland. I thank You sincerely both for Your friendly affections and especially for the astronomical news and that set of accurate observations of Yours. I am very sorry to learn that Venus has been so unfair when [only partially] exposing herself to all the other observers by the Arctic; it is like a miracle, how she uncovered herself graciously to me, who very nearly had given up all hope, but in doing so, she offered herself to be seen in such a parsimonious, and almost feminine manner, that apart from all the contacts- that is, her four kisses with the Sun, which she displayed with an uncovered face-she hid herself away with her Apollo behind a thick cloud for almost the entire duration of their rendezvous, as if being shy. I did not mind the clouds much, however, for after the observation of the first interior contact, which took place while the upper limb of the Sun was six degrees and thirty-three arc minutes high, the Sun dropped down closer and closer to the horizon, so that, during its passage through the northern meridian it was barely three degrees above the horizon. Because of the vapors of the horizon, which in this place [Vardø] are extremely dense and fluctuating so close to the horizon, it would in any case have been impossible to determine the position of Venus accurately. The interior contact of egress took place when the Sun was $10^{\circ} 4^{\prime}$, and the exterior contact when it was $11^{\circ} 13^{\prime}$ high, and they were observed by me so precisely, and in such clear and quiet atmospheric conditions, that I barely dare to doubt for more than a single second. After egress, the sky remained totally clear, without a single cloud until 3:30 p.m. on June 4, allowing me to accurately observe both the corresponding heights and the solar eclipse, and the Sun on my six-feet high meridian line. ${ }^{55}$

If Sajnovics engaged in rhetorical flourish to describe his experience of the transit, in Hell's parallel text this assumes near-poetic dimensions, even

54 Sajnovics to Splenyi in Trnava, dated Vardø, June 6, 1769 (мTAK IL).

55 Hell to Wargentin in Stockholm, dated Copenhagen, November 7, 1769 (CVH). 
employing - strikingly, in the case of a Jesuit, but very much in the voyeuristic style of a great deal of eighteenth-century literature on natural knowledgeerotic allusions to the "feminine" shyness of Venus and her "rendezvous" with the Sun as Apollo, mostly taking place under the decent veil of clouds but reaching a climax in "four kisses" that were visible to the eager spectators. But besides the artfully covert wording used by Hell and Sajnovics when they described their observations prior to February 1770, the apparent holding back of meaningful data by them needs to be further contextualized. It is helpful both to look at Hell's status and manner of procedure in 1761 and 1769 comparatively, and at the conduct of the Royal Society of Copenhagen vis-à-vis various national scientific bodies.

As of 1761 , Hell was a newcomer on the international arena. He had only recently begun expanding his network of correspondents outside the Jesuit circles of the Habsburg lands. As a corresponding member of the Académie Royale des Sciences of Paris (appointed December 1758), he shared theories and observations with several colleagues in that stronghold of theoretical astronomy. Not surprisingly, he sent the details of his Venus transit observation to Paris by letter less than a week after the event in $1761 .{ }^{56}$ This way of sharing ideas and datasets was not only in harmony with the ideals of the Republic of Letters but was also a good fit with the self-esteem of the astronomers of Paris, who considered themselves the natural coordinators of international programs such as the transits of Venus.

In the run-up to 1769 , Lalande emerged as the leading figure in the Venus transit enterprise.$^{57}$ As the elderly Delisle retreated, Lalande was issuing memoirs, offering personal advice, and placing orders at the instrument-makers on behalf of academies and individuals in various countries. It is illustrative how he advised the Imperial Academy in St. Petersburg on how to proceed, and offered to send one of his students to preside over the observations at the official observatory of that academy. Lalande also kept an assiduous correspondence

56 See Aspaas, "Le père jésuite Maximilien Hell et ses relations avec Lalande," $133-37$ (with a facsimile of Hell's letter to Lalande, dated Vienna, June 12, 1761, on 136-37). The observations of Hell were soon shared among the astronomers of Paris, who in turn communicated them to colleagues across Europe long before they had been printed (see, e.g., the letter from Lacaille to Tobias Mayer in Göttingen, dated Paris, June 28, 1761, published in Eric Forbes and Jacques Gapaillard, "La correspondance astronomique entre l'abbé Nicolas-Louis de Lacaille et Tobias Mayer," Revue d'histoire des sciences 49 [1996]: 538).

See, e.g., Pecker, "Jérôme de Lalande and International Cooperation," 52-62; Simone Dumont, Un astronome des Lumières: Jérôme Lalande, with a foreword by Jean-Claude Pecker (Paris: Vuibert/Observatoire de Paris, 2007), 36-43. Pertinent here is also the edition by Simone Dumont and Jean-Claude Pecker, eds., Mission à Berlin: Jérôme Lalande, lettres à Jean III Bernoulli et à Elert Bode (Paris: Vrin, 2014). 
with fellow astronomers in Sweden and England in this period. Not surprisingly, Lalande received news from all over the world in the weeks and months after June 3, 1769. Thus, thanks to his close contacts with astronomers on the other side of the Channel, Lalande received all British observations and summarized them in the Journal des Sçavans long before they were printed in the Philosophical Transactions. ${ }^{58}$ Similarly, the Imperial Russian Academy extracted the Venus transit observations from the expedition diaries of its observers, printed them immediately, and sent them to Lalande. And by mutual agreement, its secretary-Johann Albrecht (Jean Albert) Euler (1734-1800) - received news of French and British observations from Lalande in return. ${ }^{59}$ Furthermore, Wargentin in Stockholm summarized all Swedish (including Finnish) observations in letters to Lalande soon after the transit had taken place. ${ }^{60}$

However, no comparable agreement existed between Lalande and the Royal Society of Sciences in Copenhagen-quite the contrary, in fact. Hell's refusal to share his observations with anyone else, as explained in his letter to Wargentin quoted above, evidently included the academicians of Paris. Despite Hell's status as a corresponding member of the Académie Royale des Sciences, with none other than Lalande as his personal contact, no details whatsoever were revealed to Lalande or his confrères until a copy of Hell's Observatio transitus Veneris [...] 1769 finally reached Paris on March 4, 1770, exactly nine months after the transit had taken place. ${ }^{61}$ By that time, Lalande had received reports from all over Europe, and even from Hudson's Bay in present-day Canada. The only crucial observations he lacked were a couple of Siberian observations by Georg Moritz Lowitz (1722-74) and Ivan Islen'ev (1738-84) (published in French

$5^{8} \quad$ See JS (September 1769): 644-45; (December 1769): 835-36; (April 1770): 227-28; (December 1771): $825^{-26}$ (the last being a "letter to the editors" dated September 13, 1771, in which he explains that he had received the Tahiti observations of Cook's team two days earlier). For an analysis of Lalande's contacts with British astronomers, see Danielle M.E. Fauque, "La correspondance Jérôme Lalande et Nevil Maskelyne: Un exemple de collaboration internationale au XviıIe siècle," in Boistel et al., Jérôme Lalande, 109-28.

59 Johann Albrecht Euler to Lalande in Paris, dated St. Petersburg, May 14/26, 1769, and September 8/19, 1769 (RAN); Lalande to Johann Albrecht Euler in St. Petersburg, dated Bourgen-Bresse, July 26, 1769, and Paris, January 12, 1770 (RAN).

6o Wargentin is known to have sent letters to Lalande in Paris, dated June 9 and July 11, 1769 (see the list of outgoing correspondence in Nordenmark, Wargentin, 399-424, here 406). It is probably the contents of these letters that appeared in Lalande's "Lettre sur le passage de Vénus; Adressée à Messieurs les auteurs du Journal des Sçavans," published September 1769,645 .

61 According to Hell, "De parallaxi Solis," 92. 
in May-June 1770),62 the observations of Chappe and his companions in Baja California in present-day Mexico (which reached Paris in December 1770), ${ }^{63}$ and those of Captain Cook's crew in Tahiti, in what is now French Polynesia (which reached Paris in September 1771). ${ }^{64}$ For all these cases, there were good excuses for the delay. Lowitz continued his expedition in Siberia for several years until he was actually killed by rioting local inhabitants, ${ }^{65}$ and it took a while before the package containing his manuscripts arrived in St. Petersburg. Islen'ev's site of observation had been Iakutsk, almost 8,500 kilometers east of the capital, and even he continued his expedition for a long while before returning to St. Petersburg. Chappe, along with nearly all his travel companions, had perished from a plague while still in America; and Cook and his team had observed the transit literally from the other side of the planet and still had some explorative tasks ahead of them before they returned home. The professional astronomer of Cook's crew, Charles Green, even lost his life in Asia.

In the web of swift and open collaboration characterizing the Venus transit projects of the eighteenth century, Denmark-Norway had been-or had let itself be-left in a backwater in 1761. Its non-communicative mode of behavior continued in 1769 , and it is reasonably clear that neither Hell nor the organizers in Copenhagen asked for Lalande's advice in the planning of the Vardø expedition. The Venus transit report from Vardø did indeed arrive quite late, it was unusually—and perhaps unnecessarily—long and detailed, and both its lateness and its wealth of detail left it open to attack. Let us now briefly look at the immediate reactions to Hell's report among four of his peers who, besides being astronomers of an international reputation, had another thing in

62 On June 19, 1770, Johann Albrecht Euler sent to Hielmstierne (secretary of the Royal Society of Sciences in Copenhagen) the two reports, "which were published quite recently" (DKDVs). As of March 18, 1770, Lalande had still not received any news concerning the observations of Lowitz and Islen'ev (letter to Euler, dated Paris, March 18, 1770 [RAN]). On April 16, Lexell informed Wargentin that the manuscript of Lowitz had just arrived and was about to be printed (letter to Wargentin in Stockholm, dated April 16, 1770 [CVH]).

63 Cassini IV, "Avant-Propos" in his edition of Chappe, Voyage en Californie (Paris, 1772), unpaginated.

64 Lalande, "Lettre sur le passage de Vénus [...]," JS (December 1771): 825-26. Observations made at Jesuit observatories in China had the potential of being valuable as well. Indeed, the observations of two Jesuits-François-Marie D'Ollières (1722-80) and a certain Dollas-in Beijing are commented on by Lalande in a paper originally read in 1771 at the Académie Royale des Sciences, but he does not state when the letter containing their observations reached him, cf. Lalande "Mémoire sur la parallaxe du Soleil, déduite des observations faites dans la mer du Sud, dans le royaume d'Astracan, \& à la Chine” (1774), 789-91.

65 See, e.g., the "Précis de la vie de M. Lowitz," in Bernoulli, Nouvelles littéraires de divers pays, 6:41-50. 
common: as of the spring of 1770 , when they received the report from Vardø, they had never met Father Hell in person.

Anders Planman received his education in natural sciences in Åbo (Turku in present-day Finland) and Uppsala. As a docent of astronomy at Uppsala University, he was sent to Cajaneborg (Kajaani) in 1761 on behalf of the Royal Swedish Academy of Sciences. A couple of years later, he was appointed professor of physics at the university in Åbo, a position he kept for the rest of his life. From his base in Åbo, he presented a series of calculations of the solar parallax on the basis of the transit of Venus, arguing for a solar parallax of about 8.3 arc seconds. In 1769, Planman was again dispatched to Cajaneborg, where his observation was partly successful, insofar as he did see both the external and internal contact during ingress, but only the external contact during egress because of clouds. His datasets were reported by letter to Wargentin in Stockholm, who distributed them promptly to colleagues abroad. Like any other astronomer well versed in the noble art of calculating, Planman was eager to see the observations of his peers in order to recalculate to solar parallax from a completely new set of data. In late February 1770, Planman had not yet received the observation of Hell in Vardø. In a letter to Wargentin, he states that:

I thank my Mister [Wargentin] humbly for the observations of Venus that he has deigned to share with me, and will shortly embark upon the calculation of the solar parallax. I find Father Hell highly puzzling, since he has not yet published his observations: such a way of behaving appears rather suspicious to me. ${ }^{66}$

At that moment, Hell's report had in fact just been released, and Planman's curiosity was soon satisfied. Seeing that the observations from Vardø did not match perfectly with any other observations, Planman "free[d] him from all suspicions about the veracity of his observation."67 It might be added, however, that the Åbo professor was not only critical of the lateness of Hell's report. The swift and unpolished manner in which the Russian observations were published also had its disadvantages, mainly because they contained only the moments of contact of the transit along with the raw material for the latitude and longitude of each site, without any calculations or reductions to local mean time. ${ }^{68}$ As he explained in a dissertation presented at Åbo University on May

66 Planman to Wargentin in Stockholm, dated Åbo, February 23, 1770 (CVH).

67 Planman to Wargentin in Stockholm, dated Åbo, June 22, 1770 (CVH).

68 Planman to Wargentin in Stockholm, dated Åbo, November 17, 1770 (CVH). 
26,1770 , his own way of publishing the datasets - by an open letter first, then in brief articles in the proceedings of the Royal Academy of Sciences in Stockholm, and finally in a more elaborate dissertation - was superior to both the Jesuit of Vardø and the Imperial Academy in St. Petersburg:

In this way, it will become evident what elements of the observation are certain and settled and what are dubious. For, those who publish their data stripped of the circumstances in which they were obtained, can hardly be considered to serve the world of learning better than those who delay sharing their observations until they have had the occasion to compare them with the observations of others. Whereas the latter can hardly avoid being stigmatized by suspicion that they may have wished to publish observations that were either made up or altered in order to fit those of others, the former leave the reader in suspense as to whether or not the datasets have been obtained under appropriate conditions. Both parties are all the more to blame when considering how crucial it is, in the comparison of observations involved in the investigation of the solar parallax, to apply observations that are trustworthy in all respects. ${ }^{69}$

Although no names are mentioned, the identity of the "two parties" would be recognizable for all astronomers. A university dissertation was not necessarily shared with many outside the circle that witnessed the ceremony, but from Planman's correspondence with Wargentin, it is evident that he expected his piece to be communicated to Hell: "It would hurt me, if he [i.e., Hell] should find himself offended by my disputation; however, my lack of awareness of what came to pass [in Vardø] will serve as my excuse," he wrote in a letter shortly after the dissertation. ${ }^{70}$

The reaction of Planman, then, can be summed up as rather implicit and ambiguous. He found Hell's behavior suspicious at first, but since the datasets from Vardø turned out not to match his own, the Jesuit could hardly be accused of having forged them on the basis of the Cajaneborg observations. There was also a discrepancy between the observers in Vardø. Although the observations of Sajnovics and Hell were almost identical, the moments recorded by Borchgrevink diverged by several seconds from the two Jesuits. Planman of course noticed this fact, and noted to Wargentin that "besides, the observations of

$69 \quad$ Anders Planman and Karl Gebhard Widqvist, Expositio observationum transitus Veneris per Solem, Cajaneburgi A:o 1769, D. 3 Junii factarum [...] (Åbo: Joh. Christopher Frenckell, [1770]), [2].

Planman to Wargentin in Stockholm, dated Åbo, June 22, 1770 (CVH). 
Mister Borgrewing [sic] match my own accurately, if a solar parallax of 8.3 arc seconds is supposed. That satisfies me."71

Our next interlocutor, Anders Johan Lexell, ${ }^{72}$ was born and raised in Åbo, where he attended university and was noticed for his brilliance in mathematics. No positions were vacant in Swedish universities, however, and it may be that he had higher ambitions as well. Be that as it may, in 1768, he sent two treatises of mathematics to the Imperial Academy in St. Petersburg. Leonhard Euler (1707-83) examined them and made sure that Lexell obtained a position as his adjunctus (assistant) at the academy. One of Lexell's first tasks was to observe the transit of Venus from the academy building. He did so along with the secretary of the academy Euler and the two Jesuit visitors, Mayer and his assistant Gottfried Stahl (dates unknown). ${ }^{73}$ Having gained access to the observations from St. Petersburg, Planman commented in a letter to Euler that the observations of Lexell were the closest match to his own, under the precondition that the solar parallax was 8.3 arc seconds. ${ }^{74}$

Unlike Planman, however, Lexell was not convinced of the accuracy of his own observation - or of a solar parallax of 8.3 arc seconds for that matter. He was soon entrusted the task of calculating the solar parallax on the basis of the observations of 1769 . In this process, Lexell declined all temptation to accord the St. Petersburg observations any special reliability. Quite the contrary, in a letter to Planman dated June 25, 1770, Lexell said that

as far as Father Hell's observations of both last contacts [of Venus with the limb of the Sun] are concerned, I do not know what to say. He may perhaps have tried to fabricate them according to the Petropolitan

71 Planman to Wargentin in Stockholm, dated Åbo, June 22, 1770 (CVH).

72 On Lexell, see Johan C.-E. Stén, A Comet of the Enlightenment: Anders Johann Lexell's Life and Discoveries (Cham: Springer, 2014); his role in the Venus transit observations is discussed in Chapter 5 .

73 Stahl and Lexell used comparatively small telescopes, while the two largest and best were used by Euler and Mayer. Cf. Christian Mayer, "Expositio utriusque observationis et Veneris et eclipsis Solaris factae Petropoli in Specula Astronomica," NcASIP 13 (1769): 541-6o.

74 Planman to Johann Albert Euler in St. Petersburg, dated Åbo, September 26, 1769 (copy in Planman's handwriting, $\mathrm{CVH}$ ): "In order to be able to compare my observation with yours from St. Petersburg, it was necessary to calculate the effect of parallax with regard to these places. Assuming a solar parallax of 8.3 arc seconds, which I obtained from the observations of the transit in 1761 , I found that, after calculation, the total emersion should have taken place twenty-two seconds earlier in Cajaneborg than in St. Petersburg [...]. Thus, my observation is closest to that of Lexell and least in harmony with that of [Christian] Mayer." 
observations. In that case, he was hardly that lucky, for our observations are surely not the most accurate that exist. ${ }^{75}$

This comment was made in a private letter and would no doubt have caused a strong reaction if it had reached Hell. It is intriguing to note, however, that Lexell was convinced that the Jesuit in Vardø had made up his observations: Lexell thought there could be no other cause for the late publication than the time needed to manipulate datasets.

A man in whom Planman and Lexell both confided, Wargentin in Stockholm, evidently felt responsible for the situation. Accordingly, he asked the amateur astronomer Hellant in Torneå (now Haparanda, Tornio) to check whether the weather conditions in Vardø really had been as favorable as Hell claimed. When Hellant visited a market in Utsjoki on the borders between the Danish-Norwegian and Swedish(-Finnish) realms, a representative of the local population of Vardø confirmed that the weather had been beautiful ("smukt"). This testimony appears to have convinced Wargentin, at least. ${ }^{76}$

The leading university of the German-speaking world during the Enlightenment, the Georgia Augusta in Göttingen, had been the workplace of Tobias Mayer, who passed away in 1762. His successor, Abraham Gotthelf Kästner, may not have been an astronomer of Mayer's eminence, but he made great services to the profession as a prolific reviewer for the Göttingische Anzeigen von gelehrten Sachen. Already in the issue for April 7, 1770, Kästner published a very positive, rather long review of Hell's Vardø report. ${ }^{77}$ Kästner characterizes the method of determining the pole height as "sagacious" (scharfsinnig), and there is no hint of skepticism concerning any of the practical procedures or theoretical deliberations of Hell. Nor is it mentioned that the report arrived rather late. In sum, the overall assessment is that the Observatio transitus Veneris [...] 1769 contains "so much new and important, that this will excuse the length of this summary [i.e., review]." 78

Even more lengthy was the review in the Journal des Sçavans, which appeared in the issue for September $1770 .{ }^{79}$ Although the name of the author is suppressed, there can be little doubt about his identity—Lalande. The review is balanced. The boldness of Hell, who took upon himself this strenuous and

75 Lexell to Planman in Åbo, dated St. Petersburg, June 25, 1770 (Kansalliskirjasto, Helsinki, Planman-samlingen no. 61, transcript generously provided by Johan Stén).

76 Cf. Erik Tobé, Anders Hellant: En krönika om sjuttonhundratalets märkligaste Tornedaling. Tornedalica 49. ([Luleå]: Tornedalica, 1991), 147-49.

77 GAgS [18]:1, no. 42 (April 7, 1770): 353-56.

78 GAgS [18]:1, no. 42 (April 7, 1770): 356 .

$79 J S$ (September 1770): 619-22. 
dangerous expedition, is emphasized at the outset, and the concluding lines are certainly full of flattery of both Hell and his sponsor, the king of Denmark, who "could have made no better choice than that of giving this task to Father Hell." 80 In-between, however, the reviewer raises some objections. "We are unaware of what might have forced Father Hell to keep an important observation hidden for so long, while Europe's astronomers made haste to publish their data," ${ }^{\prime 1}$ Lalande states, without exploring the matter further. Furthermore, he strongly criticizes Hell's determination of the latitude and longitude of Vardø, which Hell had calculated through a method-"hilarious," according to the critique-differing from that explicated by Lalande in his Astronomie. He also disagrees with the Jesuit's determination of the duration of the transit, questioning his peculiar definition of the moments of "true contact" between Venus and the limb of the Sun. However, all these objections did not detract from "the importance of this observation from Vardø, the most complete that we have received from the European north." ${ }^{2}$

For all its criticism, then, Lalande's official review was written in a sober style. The stinging sentence has to do with the incomprehensible "hiding" of the observation, but that is not the same as accusing the author of fraud. "Behind the scenes," however, the tone was harsher. In a letter to the Royal Danish Society of Sciences, probably written immediately after receiving Hell's report, Lalande raised queries about the belated communication of the Vardø observation, adding threats which Hell found rather abusive. Lalande also characterized the Danish society as "virtually unknown" and wondered whether it planned to publish memoirs, and if so, when. Unfortunately, the original of the letter is lost, and we know its contents only from the travel diary of Sajnovics. ${ }^{83}$ It must be added that the criticism of Lalande was not shared by all Parisian savants. An anonymous reviewer in the Journal enyclopédique (Encyclopedic journal), May 1770, wrote very favorably about the Observatio and added flattery about "the thoroughness and clarity that are characteristic of him [i.e., Hell] and that render his works so useful for those who cultivate practical

\footnotetext{
8o JS (September 1770): 622.

81 JS (September 1770): 619.

82 JS (September 1770): 622.

83 Sajnovics's travel diary 1768-70, entry on April 3, 1770 (WUS): "A letter arrived from Lalande yesterday in which he rather arrogantly complains about the late communication of the observation to the astronomers of Paris, adding some rather abusive threats. Toward the end of the letter, he characterizes the Danish Society of Sciences as virtually unknown, and asks if it plans to publish some journal, and if so, when, etc."
} 
astronomy." No hint of skepticism is detectable, except that Hell's observation had been awaited "with impatience." ${ }^{4}$

Even though substantial parts of Hell's correspondence are lost or await discovery, there is enough evidence to demonstrate that he was informed of far harsher accusations. In a letter dated June 23, 1770, the archbishop and amateur astronomer Paul d'Albert de Luynes wrote the following:

My Honorable Father! I have received, My Honorable Father, and read with the greatest possible pleasure, the details of Your observation of Venus passing in front of the disc of the Sun. I admire Your good fortune in having had clear weather, and perfectly clear weather at that, during the two most important moments, as well as the excellent methods that You have employed to meet the lack of commodities that You were facing. Efforts have been made at our academy [i.e., the Académie des Sciences] to raise objections concerning the fact that the details of your observation reached us so late, a delay that was capable of making room for criticisms, claiming that Your lateness may give rise to suspicions that You, having had the time to receive the other observations, could have made Your observation match them. ${ }^{85}$

De Luynes did not state who had raised these allegations, but he vigorously rejected them, and assured the Viennese Jesuit of his full support. Nevertheless, at this time a five-year-long scientific controversy was already in the making, whose subject matter was not Hell's alleged manipulation of data, but the related issue of the solar parallax.

The parallax had already been a matter of debate in the aftermath of 1761 . At one end stood Alexandre Guy Pingré, who observed the transit from the Cape of Good Hope in Africa. His observation was hard to reconcile with other datasets, and besides struggles over the accuracy of his observation, Pingré had a hard time defending his solar parallax of more than ten arc seconds. At the very other end of the scale was Anders Planman, who argued for a solar parallax of about 8.3 arc seconds. In this situation, Hell opted, in the Ephemerides for the year 1764 , for a preliminary parallax of about nine arc seconds. Lalande agreed completely, and used almost exactly the same wording as Hell in the first edition of his textbook Astronomie, published in 1764. In a letter dated December 29, 1763, Lalande reveals to Hell that

84 Journal encyclopédique (May 1770): 344-52, quotation from 345.

85 De Luynes to Hell, dated Paris, June 23, 1770 (a copy in the handwriting of Hell at wUs). 
Monsieur Pingré was really annoyed because of the letter you wrote to him. He complained to me, as if I was behind it. However, it is first and foremost he himself who is to blame for criticizing in an indecent manner the observations of Yours, which are more valuable than his own. ${ }^{86}$

As we have seen, during the 1760 s Hell gradually became more self-confident and disputed not only Pingré's parallax but also some other works by French astronomers. However, before $177^{\circ}$ he seems not to have been engaged in any disputes with "the most important French astronomer of the eighteenth century." ${ }^{87}$ For all its fragmentary status, the epistolary evidence to hand suggests that Hell and Lalande remained close allies during the 1760 s. That changed with Lalande's reaction to the Vardø report.

Around the year 1761, Hell and Lalande were both "shooting stars" on the international stage. Lalande waited impatiently behind the back of Delisle to become the main nodal astronomer of the time. Hell, no less ambitious, could not dream of similar laurels but was working strenuously toward securing Vienna a firm place on the same stage. By 1769 , he succeeded, while by that time Lalande - in his own eye, certainly — emerged as the worldwide coordinator of the entire Venus transit enterprise. The first seed of discontent was probably sown when neither Hell nor Denmark-Norway asked for his advice in the planning of the Vardø expedition. But their independent behavior went beyond that. The datasets from Vardø were not shared with Lalande immediately: he had to wait in line behind the Danish king, along with every astronomer except the few Copenhagen-based savants who attended oral presentations at the sessions of the Danish Society of Sciences in November and December 1769. A third element that annoyed Lalande was the peculiar method in calculating the coordinates of Vardø, especially the pole height method described above. The fourth issue at stake was of course the conclusions drawn concerning the solar parallax itself. Unlike the previous occasion, Lalande and Hell disagreed fundamentally here. Instead of standing on the side-lines, the two stepped forward to become the main characters in a heated scientific controversy.

When calculating the solar parallax, contemporary astronomers could choose between two strategies. One option was to wait for all observations to be published and then undertake a thorough survey of all the available data. Ideally, such a survey would lead to a decisive conclusion, "the author's final word" on the matter. Another modus operandi was to make repeated calculations as the various datasets emerged. Tentative adjustments following

86 Lalande to Hell in Vienna, dated Paris, December 29, 1763, in Pinzger, Hell Miksa, 2:191.

87 Jean-Claude Pecker, "Préface," in Dumont, Un astronome des Lumières, 1-7, here 3. 
preliminary calculations would be followed by new tentative adjustments and so forth. Hell chose the former, Lalande the latter strategy. Lalande had published parallaxes of 9" (Gazette de France [January 1770]) or 9.18" (Journal des Sçavans [April 1770]) before he had access to the observation of Hell. Having received the Vardø observation as well as Chappe's from California, he adjusted it to approximately 8.75" (Gazette de France [December 1770]) or 8.80" (Journal des Sçavans [May 1771]) or again 8.75" (second edition of the Astronomie [August 1771]), until he upon the arrival of the Tahiti observation changed it yet again, to 8.50" (Gazette de France [September 1771]; Journal des Sçavans [December ${ }^{1771]}$ ). From then on, he stayed fixed on $8.50^{\prime \prime}$, or $8.60^{\prime \prime}$ as a maximum (third edition of the Astronomie [1792]).

If we look behind these numbers and pay attention to how Lalande arrived at the results, we find that he —although dismayed at its late arrival—initially held no prejudices against the Vardø observation. Quite the contrary: in a letter to Boscovich, dated December 15, 1771, he put together a table in which the observations of Cajaneborg and Vardø are compared with those of Hudson Bay, California, and Tahiti, adding that

the largest difference between the three results yielded by comparisons with Cajaneborg is 0.5 arc seconds, whereas with Vardøhus it is only $0.3^{\prime \prime}$. This makes it probable that the Vardøhusian observation is more exact than the former. Thus, if we were to take the mean between the three comparisons, staying closer to the observation of Vardøhus than that of Cajaneborg in a 5:3 relation and then taking the mean between the three last results, we get [a solar parallax of] 8.6" rather than $8.5^{\prime \prime} .{ }^{88}$

Simultaneously, Hell arrived at his conclusion of $8.70^{\prime \prime}$, which he based primarily upon his own observation from Vardø and that of Green from Tahiti. The observers in Tahiti varied several seconds between each other in their determinations of the moments of contact, but Hell stuck to the observation of the professional astronomer Green, skipping those of Admiral Cook and natural historian Daniel Solander (1733-82). The same applied for the Vardø observation, where the inexperienced Borchgrevink diverged substantially from Hell and Sajnovics. Trusting the professional and most experienced observers, Hell rejected all other observations and tried to persuade his colleagues that the

88 Lalande to Boscovich, dated Paris, December 15, 1772, cited in Vladimir Varićak, "Drugi ulomak Boškovićeve korespondencije," Rad Jugoslavenske akademije znanosti i umjetnosti, Matematičko-prirodoslovni razred $5^{2}$ (1912): ccclxviii-ccclxx. 
question of the parallax was now settled to the accuracy of $\pm 0.01^{\prime \prime} .89$ It is known that on December 20, 1771 Hell wrote a letter to Lalande, in which he tried to persuade his French colleague to exclude the observation of Planman entirely from the calculations of the parallax. ${ }^{90}$ The tone of the letter was perhaps a bit too self-confident, for by March 10, 1772, Lalande had become convinced of the opposite, as is seen in a letter to Boscovich: "What is your opinion of Father Hell, have you seen him observing, is he able, is he well trained? I conclude with the utmost dismay that his observation from Vardøhus is in accordance with no other, and that it has to be discarded."91 Similarly, he advised his colleague Bernoulli in Berlin, "do not trust the remarks of Father Hell, he is surely wrong, and this will do no honor to your work [i.e., the Receuil pour les Astronomes]. ${ }^{n 2}$

Lalande published his rejection of Hell's data in April 1772, in the Mémoire sur le passage de Vénus devant le disque du Soleil (Memoir on the transit of Venus in front of the disc of the Sun). ${ }^{93}$ Here, Lalande explained how he had found the mean solar parallax to be $8.5^{\circ}$ ", by means of virtually every other observation than that of Vardø. As for the competing observation by Planman, Lalande's conclusion was quite devastating to Hell: "This observation from Cajaneborg has become the most important among all those that were made in Europe, for it has served as confirmation and the element of comparison for all remote observations, with which it is in perfect harmony. ${ }^{\prime 94}$

Lalande's memoir was received by the Viennese Jesuit as little short of a declaration of war. In less than three months, he managed to compose-and print — an apology nearly three times the size of Lalande's work, De parallaxi Solis ex observationibus transitus Veneris anni 1769 (On the parallax of the Sun deduced from observations of the transit of Venus of the year 1769). The memoir contains both a detailed calculation of the solar parallax and a furious

$89 \quad$ Hell to Weiss in Trnava, dated Vienna, December 26, 1771, in Pinzger, Hell Miksa, 2:107-9; Hell to Fixlmillner in Kremsmünster, dated Vienna, July 17, 1772, cited in Rabenalt, "Astronomische Forschung," 117; Hell, "De parallaxi Solis," 107-8.

$90 \quad$ Hell, "De parallaxi Solis," 6.

91 Lalande to Boscovich, dated March 10, 1772, in Varićak, "Drugi ulomak Boškovićeve korespondencije," ccclxxiii-ccclxxvi.

92 Lalande to Bernoulli in Berlin, dated March 18, 1772 (Чвв), published in Dumont and Pecker, Mission à Berlin, 86 .

93 We had no access to the original but used the extensive summary in the JS (September 1772): 613-23 ("Mémoire sur le passage de Vénus devant le disque du Soleil, observé le 3 Juin 1769, pour servir de suite à l'explication de la carte publiée en 1764 [...] Paris") and other sources.

94 Lalande, Memoire sur le passage de Venus [...], 14, cited in KVAH (April-June 1772): 191. 
attack on Lalande. As Hell wrote in one of his letters accompanying the monograph (to Wargentin, dated Vienna, July 15, 1772):

If my style, so untypical of me until now, seems a little over-aggressive to you, I would like you to consider the unheard-of, and totally unfounded, accusation of having made up or altered the data, that has been put forward by Monsieur Lalande against my person (who did not exactly start my career in astronomy yesterday); this would actually have deserved a much stronger response. In more than one letter, I have advised Lalande to abstain from defending the Cajaneborg observation and cease attacking the one from Vardø, but in response to my friendly, even privately communicated advice, he has decided to brand me in public, an act I deemed I should certainly not pass by in silence..$^{95}$

Hell's confession to "over-aggression" may seem to corroborate another charge sometimes leveled against him in the literature-not just a tendency to lose his temper, but even to resort to questionable means in the heat of the debate. He is alleged to have "used all kinds of tricks; erroneous calculations, wrong longitude determinations, and incorrect parallax effects. ${ }^{\text {96 }}$ To put this in context, one might add immediately that Lexell voiced exactly the same criticism against Hell, Planman, and Lalande alike. Even Hell's insistence that Lalande must have been led more by his personal ambition than by a quest to find the truth is echoed by Lexell. In January 1770, when Lalande published his first in a series of calculations of the parallax based on the observations of 1769 , another correspondent of Wargentin's in Paris remarked that "the merit of this savant, however huge in itself, would have been doubled if only he had been less inimical to the merit of others. ${ }^{97}$ Hell was probably neither better nor worse than any in this charged contest of heavy egos.

In the De parallaxi Solis, Hell blames Lalande for having shown too much of that arrogance characterizing representatives of great powers. Lalande, he argues, must clearly have felt dismayed that neither Hell nor the court in Copenhagen asked for his advice in the planning of the Vardø expedition. Besides, he and his French colleagues were obviously offended that Hell did not dispatch an extract of his observation journal in manuscript directly to Paris, "as to a tribunal of astronomy" (tamquam ad Tribunal astronomicum), with the first express mail possible. Hence, when the report finally arrived, they judged that

95 Hell to Wargentin, dated Vienna, July 15, 1772 (CVH).

96 Kragemo, "Pater Hells Vardøhusekspedisjon," 121-22.

97 François Charles de Baër to Wargentin, dated Paris, January 18, $1770(\mathrm{CVH})$. 
it must have been "adulterated." 98 This prejudice must have brought Lalande to neglect the fact that Planman had been stationed at a site (Cajaneborg) where the Sun was extremely low above the horizon, causing the limbs of the sun to undulate strongly, whereas Hell in Vardø had enjoyed perfect atmospheric conditions and the Sun elevated more than 6.5 and $10^{\circ}$ above the sea during ingress and egress respectively. Hell meant he could prove Planman to have either defined the longitude of his site erroneously by at least thirty-five seconds, or observed the exterior contact of egress wrongly by thirty-five seconds. ${ }^{99}$ Lalande, on the other hand, who considered Hell's report worthy of rejection, had made various sophisticated calculations in order to make the Cajaneborg observation as complete as he needed it. The interior contact of egressunobserved by Planman because of clouds - was found by Lalande by altering the diameter of both Venus and the Sun by a number of seconds. In this way, he managed to fit Planman's observations to the data obtained in Tahiti and California, thereby defending his result of $8.50^{\prime \prime}$ for the mean horizontal parallax of the Sun. ${ }^{100}$ Repeatedly, Hell dismisses his Paris antagonist as "the protector and defender of the incomplete and erroneous Cajaneborg observation" and as a friend of his personal ambition rather than the truth. ${ }^{101}$ But if Planman's observation really had been as exact as Lalande wanted it to be, each and every colleague of his must have been mistaken by between twenty-four and forty-eight seconds in time. ${ }^{102}$ This absurdity would no doubt lead neutral colleagues to agree that the parallax value of Hell, rather than that of Lalande, was correct. In sum, Hell concluded that "Tahiti and Vardø will be the two columns upon which the true solar parallax of $8.70^{\prime \prime}$ will rest firmly and be preservedlike upon pillars of bronze-to the eternal memory of posterity, a memory which coming generations will decorate again and again with their palms of victory."103 For, "we are now living in a time [...] when England, Germany, Italy, Denmark, Sweden, and Russia all excel in their own astronomers, who know very well how to decide for themselves what difference there is between truth and wrong." 104

One of the "neutral" and able calculators alluded to by Hell was the young Lexell in St. Petersburg. Lexell published various attempts between the autumn of 1770 and the end of 1772 , arriving at parallaxes of $8.80^{\prime \prime}, 8.76^{\prime \prime}$, and

\footnotetext{
98 Hell, "De parallaxi Solis," 86-93.

99 Hell, "De parallaxi Solis," 8-39.

100 Hell, "De parallaxi Solis," 103-5.

101 Hell, "De parallaxi Solis," 8, 38, 86, 94, 110-15.

102 Hell, "De parallaxi Solis," 100-1.

103 Hell, "De parallaxi Solis," 109.

104 Hell, "De parallaxi Solis," 114-15.
} 
$8.63^{\prime \prime}{ }^{105}$ During the controversy, he was virtually bombarded with letters by both Hell and Lalande, and the latter even went as far as asking the pupil of Euler to act as a judge in the quarrel that had broken out between himself and the Viennese Jesuit. ${ }^{106}$ Lexell's correspondence with Hell and Lalande haswith one exception - not been available for this study. His reactions to their activities can be studied, however, in the frequent letters he sent to Wargentin in this period, all preserved in Stockholm. ${ }^{107}$ In fact, Lexell found the arguments of both Hell and Lalande unconvincing. For one thing, he was puzzled that Planman (and Lalande) was so sure about the accuracy of the Cajanbeorg observation. ${ }^{108}$ Instead of rejecting one of the observations, Lexell argued that the duration of the transit as observed in Vardø and Cajaneborg had to be adjusted by at least ten seconds in each of the two places. ${ }^{109}$ In one of his published memoirs on the parallax, we find him criticizing Lalande and Hell equally when he sums up his arguments by explaining that

I could not bring myself - contrary to all probability, and in favor of a single observation - to accuse all others of being erroneous, nor to put such faith in one particular astronomer, however experienced he may be, that I reckon him to be in possession of some sort of prerogative over others for being infallible. ${ }^{110}$

105 Anders Johan Lexell, "Determinatio accuratior verae parallaxis Solis et reliquorum elementorum," in Anonymous, ed., Collectio omnium observationum quae occasione transitus Veneris per Solem A. MDCCLXIX iussu Augustae per Imperium Russicum institutae fuerunt una cum theoria indeque deductis conclusionibus (St. Petersburg: Academia Imperialis Scientiarum, 1770), 533-74, esp. 538-39 and 556; Anders Johan Lexell, Disqvisitio de investiganda vera qvantitate parallaxeos Solis, ex transitu Veneris ante discum Solis anno 1769: Cui accedunt animadversiones in tractatum Rev. Pat. Hell de parallaxi Solis (St. Petersburg: Academia Imperialis Scientiarum, 1772), esp. 59.

106 Lexell to Wargentin, St. Petersburg, October 5, 1772 (CVH).

107 Altogether, 111 letters from Lexell to Wargentin are kept at the Centrum för Vetenskapshistoria in Stockholm. Of particular interest are his reaction to Lalande's Mémoire sur le passage, dated July 13, 1772 and his reaction to Hell's De parallaxi Solis, dated September 7, 1772 .

108 Lexell to Wargentin, St. Petersburg, July 13, 1772 (CVH): "I find it awkward of Planman to maintain that his observations are so infallible, when I can demonstrate to him that, as sure as two and two makes four, his observation of the last contact is wrong by at least ten seconds."

109 Lexell, "Disqvisitio de investiganda parallaxi Solis ex transitu Veneris per Solem anno 1769 " as printed in the Novi commentarii for the year 1772 (1773): 609-72, esp. 639-47.

110 Lexell, "Disqvisitio de investiganda [...]" (1773): 669. 
His wording in private letters is even harsher. To Wargentin, Lexell writes that Hell in the De parallaxi Solis has proven himself to be "the worst charlatan possible $[. .$.$] not even endowed with sufficient theoretical knowledge to inves-$ tigate the question of the parallax."111 His judgment on Lalande is no less severe:

What sway prejudices hold over human beings, even in such matters where they should be led by their love of truth alone, I have had occasion to witness in Lalande [...]. If every person who writes about this theme would act as honestly as him, one can easily find whatever parallax seems most agreeable. ${ }^{112}$

Another participant in the debate, Planman, followed the same line as Lalande and Lexell (who, however, did nothing to hold back his spite from Planman, either). ${ }^{113}$ In publications ranging from the beginning of 1771 until the end of 1774 , he argued for parallaxes of around $8.24^{\prime \prime}, 8.43^{\prime \prime}, 8.51^{\prime \prime}$, and finally $8.40^{\prime \prime} .114$

The debate was at its hottest in 1772. In December of that year, Planman published a dissertation where he found the parallax to be exactly as Lalande had concluded and rejected Hell's De parallaxi Solis as "a mishmash of errors" (errorum farraginem). The only data from Vardø that could possibly be used were those of the amateur Borchgrevink, he argued. ${ }^{115}$ In this turmoil, we find a single diplomatic voice: Wargentin, the network figure who stayed in close contact with all the participants in the quarrel. As Lalande, Planman, Lexell, and Hell attacked each other in public, they all confided their feelings to Wargentin as a neutral, yet influential and respected colleague. The Swede was unhappy with the strife, however, and tried his best to cool down the temperature. In a letter to Hell's confrère Weiss, dated Stockholm, March 9, 1773, Wargentin says:

\footnotetext{
111 Lexell to Wargentin in Stockholm, dated St. Petersburg, September 7, 1772 (CVH).

112 Lexell to Wargentin in Stockholm, dated St. Petersburg, February 25, 1771 (CVH).

113 See Stén, Comet of the Enlightenment, $75^{-76}$.

114 Anders Planman, "Formuler, At Uträkna Parallaxens verkan för observerade in- och utgångs momenter, vid en Planets gång under Solen," in KVAH (January-March 1771): 66-74; Planman, "Om Solens Parallaxis, i anledning af Observationer öfver Venus i Solen, år 1769," KVAH (April-June 1772): 183-91; Anders Planman and Johan Kreander, Animadversiones Subitanece in Appendicem Hellianam ad Ephemerides anni MDCCLXXIII, De parallaxi Solis (Åbo: Johannes Christoph Frenckell, 1772); Planman, "Förklaring på de Formler, at uträkna Parallaxens verkan, för observerade in- och utgångs-momenter vid en Planets gång under Solen, som anfördes uti Handlingarne för år 1771," KVAH (October-December 1774): 306-19.

115 Planman and Kreander, Animadversiones subitanece, 12.
} 
I strongly dislike the all too harsh controversy that has arisen between Lalande, Hell, and Planman, over the observations of the last transit of Venus. There ought to be no doubt that both Hell and Planman have exerted all their efforts - their eyes as well as their intellect - while observing, and that they have published it bona fide. They may have made mistakes of a few seconds each, for they are, after all, human beings [...]. The safest solution would therefore have been to concede something to each observer, by placing one's faith in a mean parallax, calculated on the basis of both observations. ${ }^{116}$

The effect of Wargentin's (and perhaps other sensible minds') diplomacy can be seen in the Journal des Sçavans for February 1773, where Lalande allowed the printing of a "letter concerning the calculations by Monsieur Lexell and Father Hell" as well as a "letter on the solar parallax."117 The tone had become milder.

Father Hell [...] appeared to declare war on all the astronomers of Paris in his booklet, by contesting the quality of the observation of Monsieur l'Abbé Chappe, by bringing back old disputes concerning the alleged moon of Venus, the longitude of Vienna, the geodetic measurements made in Germany [...], but he should make these concessions to me: that our correspondence has always been filled with friendship and respect from my part, that I have praised him on every occasion, and that I have never given place in our dispute for any personal complaints except that which concerns his having made the astronomers wait for so long for an observation that was so necessary to them. ${ }^{118}$

Furthermore, Lalande was careful not to attack Lexell, and even admitted some errors in the Memoire sur le passage that the latter had pointed out. As to the parallax, he still believed that the value of $8.50^{\prime \prime}$, or a maximum of $8.55^{\prime \prime}$, was most likely to be true. But with surprising humbleness he added: "To sum up, if the parallax is 8.55 arc seconds or 8.70, the difference is no more than a fifty-seventh part of the total, and the expedition of Father Hell will nevertheless have the advantage of having contributed to draw closer the limits of our

116 Wargentin to Weiss in Trnava, dated Stockholm, March 9, 1773, in Vargha, Correspondence de Weiss, $106-7$.

117 JS (February 1773), "Lettre sur les calculs de M. Lexell et du P. Hell" (90-93) and "Lettre sur la parallaxe du Soleil” (113-15).

118 JS (February 1773): 113. 
uncertainties."119 A rapid exchange of letters between Hell and Lexell in the winter of $177^{-1} 73$ also ended in a sort of reconciliation. Hell in fact took the liberty of publishing one of Lexell's letters in his Ephemerides, but added to almost every sentence such long and intricate footnotes that, in effect, the voice of Lexell was almost drowned. ${ }^{120}$ Remarkably, Hell recognized that he had committed several errors in the calculations of the De parallaxi Solis (although he blamed the printer for a number of the mistakes), but refused to alter his initial conclusion: the parallax, he maintained, was still nothing short of $8.70^{\prime \prime}$, or $8.70^{\prime \prime} \pm 0.03^{\prime \prime}$ at the most. ${ }^{121}$

Simultaneously, Pingré was busy presenting a series of lectures to the Académie des Sciences, where he concluded that the solar parallax had to be $8.80^{\prime \prime}$, "quite accurately" (à très-peu-près)..$^{122}$ The approach of Pingré was more openminded than that of Hell or Lalande. The only thing he rejected was the exterior contact of egress as observed in Cajaneborg; Planman's ingress data could still be used, he argued. As for Tahiti, Pingré upon investigation found that the observation of Green had to be left out; the same he did with Borchgrevink's data from Vardø. He even tested thoroughly Rumovskii's observation from Kola, something Lalande, Lexell, and Planman had all neglected. ${ }^{123}$ Lalande was upset but felt confident that he would be able to make a fool of Pingré, as he said in a letter to Wargentin. ${ }^{124}$ Hell, on the other hand, felt an enormous relief. The difference between their conclusions- $8.80^{\prime \prime}$ instead of $8.70^{\prime \prime}-$ he found to originate from Pingrés use of Cook's observation rather than that of Green. But this was hardly any offense: the Jesuit father found that his credibility had been restored and the notorious egress data from Cajaneborg had been rejected from the calculations. ${ }^{125}$

119 JS (February 1773): 115.

120 Letter from Lexell to Hell in Vienna, dated St. Petersburg, February 22, 1773, printed in the "Supplementum dissertationis de parallaxi Solis," Ephemerides 1774 (1773): 1-162, here $15^{-68 .}$

121 Hell, "Supplementum dissertationis de parallaxi Solis," 62. It must be added that after having seen Hell's "Supplementum," on December 24, 1775 Lexell wrote about it with bitter irony to Bernoulli- "I found it to be just as I imagined and even worse" - and reproached the Swiss sage for "the remarkable contrast between your conduct towards me and father Hell." Cited in Stén, Comet of the Enlightenment, 76-77.

122 Pingré, "Mémoire sur la parallaxe du Soleil, déduite des meilleurs observations de la durée du passage de Vénus sur son disque le 3 Juin 1769," HARS (1775): 419.

123 Hell had, it is true, presented a brief investigation of Rumovskii's observation and concluded that it gave a parallax of $8.73^{\prime \prime}$, but without putting much weight on this; cf. Hell, "De parallaxi Solis," 80-84.

124 Lalande to Wargentin in Stockholm, dated Paris, January 5, 1773 (CVH).

125 Hell to Weiss in Trnava, dated Vienna, April 6, 1773, in Pinzger, Hell Miksa, 2:114-17. 
At least publicly, Lalande appears to have carried no more logs to the fire. And after publishing his bulky Supplementum to the memoir De parallaxi Solis in the autumn of 1773 , Hell too withdrew from the debate. Planman published an apology against this last work of Hell in 1774. He there argued for a probable parallax of $8.40^{\circ}$, but the article appears not to have been widely disseminated. ${ }^{126}$ Lexell groaned to Wargentin that the Jesuit could only have had two reasons for publishing a private letter of his in the Supplementum, the first being a desire to defend his conclusion of 8.70 " for the parallax, and the second, a desire to hurt Lexell's reputation. Lexell explained that he too planned to publish another apology against Hell, "if the academy agrees to its publication," but this plan appears to have come to nothing. ${ }^{127}$

The strife ended there, with parallaxes ranging from $8.40^{\prime \prime}$ (Planman) to 8.80" (Pingré). Hell's abilities as an observer and calculator were brought into question, and by the time the debate subsided in the mid-1770s, he was an exJesuit. To what extent did religious antagonism play a role in the controversy? The debates following his Venus transit observation of 1769 have been described as "symptomatic of the highly charged feelings the Jesuits elicited on the eve of the dissolution of the Order." 28 The biographer of Hell's successor as director at the Vienna Observatory even suggests that Lalande as an atheist was a personal enemy of the Jesuits, "aggressively waging war against them."129 Elsewhere, we also read of "the unfair suspicion of a notorious atheist against a priest with a predestined name."130

These characterizations are hard to corroborate. Lalande helped the Jesuit Christian Mayer go to St. Petersburg for the same purpose as Hell had traveled to Norway, and he cultivated a close friendship with Father Boscovich throughout the dispute with his confrère in Vienna. Lalande, himself a pupil of the Jesuits, is in fact known to have deplored the abolition of their "illustrious society."131 Admittedly, in letters to Wargentin written in the heat of the moment Lexell did not hesitate to dismiss the arguments of his Viennese counterpart as

126 Planman, "Förklaring På de Formler."

127 Lexell to Wargentin in Stockholm, dated St. Petersburg, June 11/22, 1774 (CVH).

128 Mordechai Feingold, "Jesuits: Savants," in Feingold, Jesuit Science and the Republic of Letters, $1-46$, here 1 .

129 Kastner-Masilko, Triesnecker, 48.

130 Jean-Claude Pecker, "L'oeuvre scientifique de Joseph-Jérôme Lefrançois de Lalande (17321807)," Les nouvelles annales de l'ain (1985): 1-31, here 19. It should be mentioned that Pecker later revised his opinion on the quarrel between Lalande and Hell; cf. Pecker, "Jérôme de Lalande and International Cooperation."

131 See, e.g., Heilbron, Electricity in the 17th and 18th Centuries, 109. 
sophisms characteristic of a Jesuit. ${ }^{132}$ But such sentiments were never voiced in any serious, scientific publication on the parallax, nor did Lexell brand Hell for being Jesuit in his correspondence with him. ${ }^{133}$ Much more conspicuous is Hell's polemic against French science as a whole. Whereas Hell in his survey of observations of the 1761 transit of Venus had extolled France as "the highly fertile parent and nurse of the best astronomers of our age," in the De parallaxi Solis of 1772 he criticized virtually anything the French did. ${ }^{134}$ In the meantime, France had of course expelled the Jesuits (begun around 1761, finished by 1768) and was pressing the pope to order the same for every Catholic country. Hell is careful to protect against criticism not only his own observation from Vardø but also that of Jesuit missionaries in Beijing. ${ }^{135}$ In fact, the Viennese Jesuit appears to have been more biased against Lalande — as a representative of French science - than anyone else, Lalande included, was against him as a Jesuit. Lalande, in his turn, reconciled himself fully with Father Hell. This is well illustrated by the éloge read by him at the Académie des Sciences (the post-revolutionary Institut National) upon the death of his correspondent:

The [Vardø] observation of Father Hell [...] was a complete success; [...] it is in fact one of five complete observations that were made at huge distances from each other, where the positioning of Venus during its passage shifted the most. This has made us know the true distance of the Sun and all the planets from the Earth, an epoch-making feat in the history of astronomy, in which the name of Father Hell is deservedly inscribed. His expedition was just as rewarding, interesting, and painstaking as those made to the southern sea, to California, and Hudson Bay, for the sake of this famous transit of Venus in front of the Sun. ${ }^{136}$

132 Letters from Lexell to Wargentin in Stockholm, dated St. Petersburg, April 12, 1772, September 7, 1772, and March 23/April 3, 1773 (all located in the CVH).

133 Lexell to Wargentin in Stockholm, dated St. Petersburg, March 23/April 3, 1773 (CVH): "I have ensured him, that I find such petty arts loathsome, childish and ridiculous; I thought that they were worthy of a Jesuit, but I did not say so." It is also worth noting that Lexell developed a close friendship with the Jesuit Christian Mayer during his stay in St. Petersburg and recommended him to Wargentin; Lexell to Wargentin, St. Petersburg June 10/11, 1770 (CVH). Thus, neither Lexell nor Lalande were unequivocally biased against Jesuits as such.

134 Contrast Hell, "Observatio transitus Veneris [...] 1761," 36, and Hell, "De parallaxi Solis," $111-14$.

135 Hell, "De parallaxi Solis," 79-80.

136 Joseph Jérôme de Lalande, Bibliographie astronomique: Avec l'histoire de l'astronomie depuis 1781 jusqu’à 1802 (Paris: Imprimerie de la République, 1803), 722. 
At the end of our analysis of the Arctic expedition and its aftermath, it is tempting to briefly reflect comparatively on the status of Hell's journey and that of Maupertuis to the same region a good generation earlier. ${ }^{137}$ Besides the geographic proximity of the targeted area, several other factors warrant such a comparison. In both cases, a savant with already strong credentials and claims to celebrity status on the domestic and international scene ventured into the frost of the north with the goal of solving scientific problems of cosmic significance: the shape of the Earth in the one case, and the distance of the planet from the center of the solar system in the other. True, Maupertuis was far more successful in publicizing his identity in his Figure de la terre (Shape of the earth [1738]) and other works as a "hero of science" than Hell, whose design of the Expeditio litteraria became frustrated. But it is undeniable that Hell put as great an emphasis as his French predecessor on the combination of scientific expertise, resourcefulness, and accuracy required to meet technical challenges, with courage and physical prowess necessary to combat and conquer the adversity of circumstances, in reframing his persona. In this regard, the iconographic parallels between the image on our title page and the famous portrait of Maupertuis-originally conceived as a painting, and subsequently reproduced and distributed in a different version as an engraving ${ }^{138}$ — both of them emphasizing the features just mentioned, are telling. By both Maupertuis and Hell, the good fortune with which their expeditions were ultimately blessed was represented as the reward of their perseverance, although the latter naturally accorded divine providence an important role, too-an element unsurprisingly missing from the accounts of the French libertine. In turn, while the sudden appearance of two "Lappish" (in reality, Swedish) women in Paris shortly after the return of the notorious womanizer of the beau monde gave rise to a flurry of gossip, this could hardly have been imaginable in the case of the Viennese Jesuit. The bitter polemics that ensued around the outcome of both expeditions constitute a further parallel, even though the reasons for and the substance of the debate were rather different. For Maupertuis, the emphasis on the shape of the Earth as a scientific problem in its own right, to be resolved by resorting to English instruments and mathematical skills, with a view to developing a distinctively French Newtonian physics, was a means to challenge a set of views and a whole way of life entrenched in the French academy and hallmarked by the Cassini dynasty, for whom the shape of the Earth was also a mere byproduct of a cartographic project pursued over several

137 Terrall, Man Who Flattened the Earth, esp. 88-172, which serve as the chief basis of comparison.

138 See Terrall, Man Who Flattened the Earth, frontispiece and 162. 
generations. By contrast, the debate occasioned by Hell's Vardø observations was broadly international, and while issues of methodology were involved, considerations of loyalty and factors of patronage were at least as important. Despite—or precisely because of — such differences, both cases throw important light on the nature of the fissures that, without doubt, divided the eighteenth-century Republic of Letters. ${ }^{139}$

Despite the periods of embitterment and venom between Hell and his adversaries, during his lifetime he was never overtly accused of having forged his observations from Vardø. However, the debate had a peculiar Nachleben (afterlife), apparently not unrelated to the climate of hostility against Jesuits and their legacy during the post-suppression decades. Two astronomers of the next generation, Johann Franz Encke (1791-1865) and Karl Ludwig von Littrow (1811-77), were particularly active in denigrating Hell's name.

The child of a Lutheran pastor in Hamburg, Encke was educated by Carl Friedrich Gauss (1777-1855) at Göttingen. Thanks to Gauss's recommendation, in 1816 he gained a post as an assistant at the observatory at Seeberg near Gotha. ${ }^{140}$ The director of the observatory was Franz Xaver von Zach (1754-1832), born in Pest, the twin city of the old Hungarian capital Buda just across the Danube, and the little we can know about his education suggests that he probably studied with Jesuits. From a troubled start as Liesganig's assistant in Lviv for the geodetic survey of Galicia, he embarked upon a tour of Europe that eventually brought him from London to a position as court astronomer in Gotha, in $1786 .{ }^{141}$ From his base in peaceful Gotha, von Zach became a highly successful "networker" who published extensively. He became a staunch antagonist of the (ex-)Jesuits, and both Liesganig and Hell were frequently attacked in his writings. A point that von Zach pursued with particular vigor was Hell's "withholding" of the Vardø observation results:

\footnotetext{
139 See Daston, "Ideal and Reality of the Republic of Letters," 367-86.

140 For Encke's life, see August Kopff in Neue Deutsche Biographie 4 (Berlin: Duncker \& Humblot, 1959), 489-9o; Michael Meo in Biographical Encyclopedia of Astronomers, ed. Thomas Hockey et al. (New York: Springer, 2014), 1:661-62.

141 See Lajos G. Balázs et al., eds., The European Scientist: Symposium on the Era and Work of Franz Xavervon Zach (1754-1832), Acta Historica Astronomiae 24 (Frankfurt am Main:Verlag Harri Deutsch, 2005); Peter Brosche, Der Astronom der Herzogin: Leben und Werk von Franz Xaver von Zach (1754-1832), 2nd ed., Acta Historica Astronomiae 12 (Frankfurt am Main: Verlag Harri Deutsch, 2009).
} 
Father Hell had all the time in the world to adjust his observation (not upon the calculation [...], but upon the numerous observations of other observers who had published their reports earnestly). Father Hell excused himself by stating that the observation was not his own property and that he could not share it with others, nor make it public, until he had paid tribute to the king of Denmark, who had asked for Father Hell from Empress Maria Theresa in order that he should make this observation in his estates. However, an astronomical observation is not a state secret, and you hardly need nine months to print the couple of lines required to explain the entire observation. ${ }^{142}$

When in the 1820s Encke took upon himself the task of re-calculating the solar parallax on the basis of the observations of the $1760 \mathrm{os}$, he was thus liable to a certain degree of skepticism toward the datasets from Vardø.

Encke first issued a calculation of the solar parallax based on all observations from 1761 . This yielded a parallax of $8.490525^{\prime \prime},{ }^{143}$ a figure in perfect agreement with Lalande's position. When he proceeded to investigate the issue on the basis of observations from 1769 , Encke clearly had no doubts that the late Jesuit could have been capable of manipulating his datasets. As he saw it, Hell's calculations of the solar parallax were of no value, his abilities as an observer more than questionable, and his excuses for his report's late arrival "utterly futile."144 Accordingly, in a treatise on the solar parallax based on the observations from 1769, Encke found on the basis of all observations-Hell's excluded - a parallax of $8.5776^{\prime \prime} \pm 0.037^{\prime \prime} .{ }^{145}$ When he included the data of the Jesuit in the calculation, the result was 8.60". As Encke himself conceded, that difference was "well within the limits of likely error." 146 However, given that his earlier investigation based on the 1761 observations had yielded 8.49", Encke

142 Franz Xaver von Zach, Correspondance astronomique, géographique, hydrographique et statistique du Baron de Zach (Genoa: A. Ponthenier, 1818), 1:176.

143 Encke's Die Entfernung der Sonne von der Erde aus dem Venusdurchgänge von 1761 hergeleitet (Gotha: Becher, 1822) could not be consulted. The parallax value is, however, given in Verdun, "Die Bestimmung der Sonnen-Parallaxe."

144 Johann Franz Encke, Der Venusdurchgang von 1769 als Fortsetzung der Abhandlung über die Entfernung der Sonne von der Erde (Gotha: Becker, 1822), passim (quotation on 18).

145 Encke, Der Venusdurchgang von 1769, 109.

146 Johann Franz Encke, "Über den Venusdurchgang von 1769," Abhandlungen der Königlichen Akademie der Wissenschaften zu Berlin: Mathematische Klasse (1835; published 1837): 295-309, here 302: "The inclusion of the Vardøhusian observation yielded a parallax of 8.60 arc seconds, whereas all the other observations, the Vardøhusian excepted, yielded 8.58, a difference [etc.]." 
was reluctant to pay heed to the Vardø observations at all. Like Lalande had done earlier, he simply discarded them. Unlike Lalande, however, Encke did not refrain from giving voice to prejudices against Father Hell as a representative of the Jesuit order.

Shortly before Encke made his calculations, a regime change had taken place at Hell's observatory in Vienna. Hell's one-time assistant and successor, the ex-Jesuit von Triesnecker, died in 1817. Von Triesnecker's assistant Johann Tobias Bürg (1766-1834), who had been attached to the observatory since the 1780 , was not viewed as a suitable candidate for the post because he was deaf. ${ }^{147}$ Instead, the new director was recruited from outside. Originally educated in Prague, Johann Joseph von Littrow (1781-1840) rose to the director's chair of the Vienna University Observatory in 1819 after posts as an astronomer in Kraków, Kazan, and Buda. Shortly afterward, the observatory acquired the collection of manuscripts by Hell that it still keeps today. Johann Joseph gave the task of investigating Hell's papers to his son, the observatory adjunct Carl Ludwig von Littrow.

The results were published in 1835 , in the sensational book $P$. Hells Reise nach Wardoë (Father Hell's journey to Vardø). ${ }^{148}$ One of the charges against Hell that von Littrow — almost naturally — revived was the "delay" of the publication of his data:

A circumstance that appears to be worth pointing out is that in the entire diary [of Sajnovics] there is no trace to be found of the ban that was supposed to have been issued by the king of Denmark against publication of the Vardø observation. This fact confirms the assumption that has already been put forward, that the whole thing may well have been invented by Father Hell, to serve him as an excuse for the late publication of his report. ${ }^{149}$

Besides the points already made above regarding the possible commitment vis-à-vis the sponsor of the expedition, it may be reiterated here that the part of Sajnovics's diary covering this period has been lost, along with nearly all his letters written from Copenhagen.

\footnotetext{
147 Kastner-Masilko, Triesnecker, 72.

148 According to Axel V. Nielsen, "Pater Hell og Venuspassagen 1769," Nordisk Astronomisk Tidsskrift (Copenhagen) (1957): 77-97, here 96n27, it had already been printed in 1834, despite the information on the title page.

149 Karl Ludwig von Littrow, P. Hell's Reise nach Wardoe bei Lappland und seine Beobachtung des Venus-Durchganges im Jahre 1769: Aus den aufgefundenen Tagebüchern geschöpft und mit Erläuterungen begleitet (Vienna: Carl Gerold, 1835), 163.
} 
Upon inspection of the astronomical notebook, the younger von Littrow also concluded that Hell had altered and manipulated the datasets, often with a different kind of ink. He claimed that the Venus transit observations of Hell and Sajnovics - as published by Hell in the Observatio transitus Veneris [...] 1769 - were worthless, whereas that of the untrained Borchgrevink, whose moments differed many seconds from those of the two Jesuits, was "the only true" observation and could be used. ${ }^{150}$ Von Littrow thereby restored the Vardø observations, but in doing so, he furnished the reader with "proofs" of Hell's unreliable character and incompetence as a scientist. Through von Littrow's book, the name of Hell became tainted with the worst thinkable scientific crime: manipulation of datasets.

Von Littrow's publication found an immediate response from the expert on the solar parallax to whom it was dedicated, Encke. At a session of the Berlin Academy of Sciences on April 30, 1835, Encke explained that his skepticism toward the veracity of Hell's Vardøhus observation originated in the general impression that he had formed of his personality, first and foremost because "he was a Jesuit."151 Encke had now gladly embraced von Littrow's account and found that it confirmed all his prejudices toward the late Viennese Jesuit, who clearly not only had altered his datasets in a very clumsy and incompetent manner but had also been unable to keep correct track of the running of his clocks and had calculated the longitude and latitude of Vardø wrongly. Thanks to von Littrow's edition of the original astronomical notebook of Hell, Encke was now able to apply what he believed to be the necessary reductions of all the data. He entered the "restored" Vardø observation into his calculation, and found that it supported a solar parallax of 8.57116", only 0.0064" different from the one he had found without using the Vardøhusian datasets ten years earlier. ${ }^{152}$

The conclusions of the 1830 s remained unchallenged for more than three decades. In 1864, however, astronomer Karl Rudolph Powalky (1817-81) at the University of Kiel defended a doctoral thesis on the Venus transit of 1769 and the solar parallax that could be calculated thereof. He inspected von Littrow's book as well as Encke's treatises, but could not bring himself to agree to their hostile conclusions. Instead, Powalky found that

the corrections that Hell allowed himself to make in his manuscript appear to have been extremely unimportant. This, the good quality of the

$150 \quad$ Von Littrow, P. Hell's Reise nach Wardoe, 77.

151 Cf. Encke, "Über den Venusdurchgang von 1769," 301.

152 Encke, "Über den Venusdurchgang von 1769," esp. 309. 
telescopes used by himself and Father Sajnovics and the good accordance of the contacts observed during egress along with the remarks made on this occasion allow the observations to be treated as quite certain. [...] Furthermore, one should note that Hell and Sajnovics were skilled observers and that the Sun was higher above the horizon during both ingress and egress than in any other site in Europe, with the exception of Orenburg [in Russia], where only the egress was observed. ${ }^{153}$

In his thesis, Powalky concluded that the solar parallax probably was around $8.86^{\prime \prime}{ }^{154}$ thus far larger than Encke's conclusions and more in tune with Hell.

In 1869, a prominent astronomer at the Académie des Sciences in Paris, Hervé Auguste Étienne Albans Faye (1814-1902), presented a paper in which he questioned some of Encke's and von Littrow's conclusions, particularly concerning the solar parallax (Faye advocated a solar parallax of $8.80 \pm 0.01$ ", which is indeed entirely correct). ${ }^{155}$ Carl Ludwig von Littrow, who in the meantime had been appointed director of the Vienna Observatory, reacted promptly by dispatching facsimiles of Hell's manuscript to Paris. Of course, Professor Faye had no chance of detecting errors in von Littrow's conclusions on the basis of the sets of black-and-white reproductions offered to him. In a follow-up article, he therefore agreed that the original journal must indeed have been edited before publication. Nevertheless, while admitting that Hell had arrived at some misguided conclusions in his theoretical works, he maintained that the editing in any case had been made with the best of intentions and underscored that Hell's original manuscript proved his abilities as an observer. Looking ahead to the upcoming transit of Venus, Faye concluded that "the error of Father Hell's observation, which he made without understanding its meaning, thus does not exceed 2.2 seconds in time. It will be difficult for us to do any better in 1874 ."156 The solar parallax question was not resolved by the new sets of international observations of the Venus transit in 1874 , and the Swiss astronomer Rudolf Wolf (1816-93) in his Geschichte der Astronomie (History of

\footnotetext{
153 Carl Rudolph Powalky, Neue Untersuchung des Venusdurchganges von 1769 zur Bestimmung der Sonnenparallaxe (Kiel: C.F. Mohr, 1864), 15-16.

154 Cf. Hilmar W. Duerbeck, "Zach, Gotha, and the Venus Transits of the 18th and 19th Centuries," in Balázs et al., European Scientist, 60.

155 Hervé Auguste Étienne Albans Faye, "Sur les passages de Vénus et la parallaxe du Soleil" [parts 1-2], Comptes rendus hebdomadaires des séances de l'Académie des Sciences 68 (1769): 42-50 and 69-73; Faye, "Examen critique des idées et des observations du P. Hell sur le passage de Venus de 1769," Comptes rendus hebdomadaires des séances de l'Académie des Sciences 68 (1769): 282-9o. See also Nielsen, "Pater Hell og Venuspassagen 1769."

${ }_{156}$ Faye, "Examen critique," 287. See also Faye, "Sur les passages," esp. 47-49 and 70.
} 
astronomy [1877]) still believed in von Littrow's and Encke's conclusions concerning Hell. Though Wolf, like Faye, conceded that the solar parallax probably was somewhat larger than Encke had concluded, ${ }^{157}$ the main blemish on Hell's memory, the crime of having manipulated a set of scientific data, remained. Thus, when an article on him was included in the Allgemeine Deutsche Biographie (General German biography, vol. 11 [1880]), the story of his fraudulent alteration of the Venus transit observation from Vardø was repeated without any reservation. ${ }^{158}$

Only three years later, Simon Newcomb (1835-1909) published his remarkable demonstration that von Littrow was plainly wrong, a conclusion he further corroborated in his later works. During a study trip in the early 1880 s, Newcomb visited the Viennese observatory, where he took the opportunity to investigate the notorious manuscripts of Hell. First, the manuscripts inspected by von Littrow-with one insignificant exception, which he overlooked-in fact contained no additions in a different-colored ink, as he claimed: as Newcomb discovered, the young von Littrow had been so blinded by his prejudices against the late Jesuit that he forgot to consider that he himself was in fact colorblind. ${ }^{159}$ Second, regarding the issue of the parallax, Newcomb could draw upon experience from the transits of Venus in both 1874 and 1882, and his conclusion concerning the solar parallax was virtually identical to the one advocated by Faye in 1869. The datasets from Vardø corroborated this conclusion. Thus, Hell's Vardø observations turned out to support a parallax of 8.79" (Newcomb) or 8.80" (Faye), and have since then been "canonized."160 Newcomb's demonstration found a reverberant echo among Jesuit apologists. The

157 Rudolf Wolf, Geschichte der Astronomie, Geschichte der Wissenschaften in Deutschland: Neuer Zeit, Sechzehnter Band (Munich: R. Oldenbourg, 1877), 645-46.

$15^{8}$ Christian Bruhns in Allgemeine Deutsche Biographie 11 (Leipzig: Duncker und Humblot, 1880), 691-93, here 692. See also Nielsen, "Pater Hell og Venuspassagen 1769," for more examples.

159 Simon Newcomb, "On Hell's Alleged Falsification of his Observations of the Transit of Venus in 1769," Monthly Notices of the Royal Astronomical Society 43 (May 1883): 372-81; Newcomb, "Discussion of Observations of the Transits of Venus in 1761 and 1769," United States Nautical Almanac, Astronomical Papers 2, no. 5 (189o): 259-405. Cf. Newcomb, The Reminiscences of an Astronomer (Teddington: Echo Library, 2006 [1903]), 78-82. For a brief assessment of Newcomb's career, see William Carter and Merri Sue Carter, "Simon Newcomb, America's First Great Astronomer," Physics Today 62 (2009): 46-51.

160 Recent advances in electronic measuring have brought the solar parallax to be fixed at 8.794148". Ian Ridpath, entry on "solar parallax" in A Dictionary of Astronomy (Oxford: Oxford University Press, 2007), 431. The number of decimals could probably have been expanded. To translate it into familiar terms, this means that the Sun, in its mean distance from Earth, "is a couple of meters shy of 149,597,870,700 m[eters]" away. E. Myles Standish, "The Astronomical Unit Now," in Kurtz, Proceedings, 163-79, here 174. 
Jesuit-run periodical Stimmen aus Maria Laach (Voices from Maria Laach, later renamed Stimmen der Zeit, Voices of the time) repeatedly announced Newcomb's detection as a remarkable feat, ${ }^{161}$ and the German Jesuit historian Bernhard Duhr (1852-1930) included it in his widely read Jesuiten-Fabeln (Jesuit fables). ${ }^{162}$ Eventually, the "vindication of Father Hell" became a topic of academic discussion in its own right. ${ }^{163}$

161 Johann Georg Hagen, "Washington und seine wissenschaftlichen Institute," Stimmen aus Maria Laach 34 (1888): 551-53; Ludwig von Hammerstein, "Der Astronom P. Hell S.J. und sein Verteidiger Professor Simon Newcomb," Stimmen aus Maria Laach 39 (1890): 455-58; Hagen, "Karl Littrow als Geschichtsforscher," Stimmen der Zeit 93 (1917): 108-14.

162 Bernhard Duhr, Jesuiten-Fabeln: Ein Beitrag zur Culturgeschichte 2nd ed. (Freiburg: Herder, 1892), 465. Altogether, four editions of this book appeared in the years 1891-1904.

163 George Sarton, "Vindication of Father Hell," Isis 35 (1944): 97-105. 